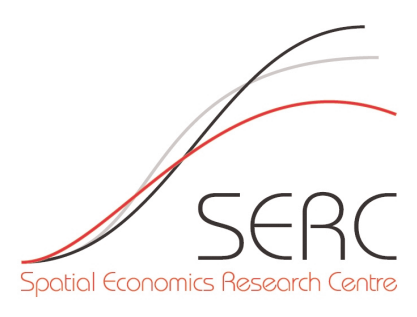

SERC DISCUSSION PAPER 141

Do Long Distance Moves

Discourage Homeownership?

Evidence from England

Sejeong Ha (LSE)

Christian A. L. Hilber (SERC, LSE)

September 2013 
This work is part of the research programme of the independent UK Spatial Economics Research Centre funded by a grant from the Economic and Social Research Council (ESRC), Department for Business, Innovation \& Skills (BIS) and the Welsh Government. The support of the funders is acknowledged. The views expressed are those of the authors and do not represent the views of the funders.

(C) S. Ha and A.L. Hilber, submitted 2013 


\title{
Do Long Distance Moves Discourage Homeownership? Evidence from England
}

\author{
Sejeong Ha* \\ Christian Hilber**
}

September 2013

* London School of Economics

** SERC and London School of Economics

\section{Acknowledgements}

We thank Paul Cheshire, Daniel Graham, Jan Rouwendal and seminar participants at the London School of Economics for helpful comments and suggestions. This paper builds on and further refines a PhD dissertation chapter in Ha (2013). All errors are the sole responsibility of the authors. Address correspondence to: Christian Hilber, London School of Economics, Department of Geography and Environment, Houghton Street, London WC2A 2AE, United Kingdom. Phone: +44-20-7107-5016. Fax: +44-20-7955-7412. E-mail: c.hilber@lse.ac.uk 


\begin{abstract}
We hypothesize that as the distance of a residential move increases, the cost of collecting information on the destination housing market rises, the amount and quality of information collected fall, and the chances of making an ill-informed housing purchase decision increases, reducing the likelihood of such a purchase. Since owning relative to renting is associated with a much larger financial commitment and much higher transaction costs, the propensity to own can be expected to decrease with the distance moved. Using data from the Survey of English Housing from 1993 to 2008, we document that, consistent with our prior, an increase in the distance moved by one standard deviation decreases the probability that a household owns the next home by 3.2 percentage points.
\end{abstract}

Keywords: Residential mobility, distance of residential relocation, information cost, investment risk, homeownership, tenure choice

JEL classification: J61, R21, R23 


\section{Introduction}

The decisions 'whether to own or rent a home', 'where to buy', and 'what property to buy' are all risky. Ill-informed purchases cannot easily be reversed. This is because, unlike most other financial assets, residential properties are quite illiquid and homeownership is, in most countries, associated with very high transaction costs ${ }^{1}$.

Ill-informed purchases also greatly adversely affect a household's long-term wealth situation. This is because households that want to own their home typically have to invest a large share of their savings into one single volatile asset; their home. Moreover, most homebuyers dramatically leverage this investment by taking on a substantial mortgage. In other words: most homebuyers overinvest into residential real estate from a portfolio diversification point of view. If the value of the home increases, this has dramatic positive wealth effects. Conversely, if the value drops (or has been overestimated in the first place), this often wipes out a household's entire wealth. This is especially true for first-time purchases since in this case there is no previous property that could provide a hedge of the form 'sell low-buy low; sell high-buy high'. However, even 'chain-transactions' (sell old house and buy new one) are associated with significant idiosyncratic risk components that cannot easily be hedged away. For example, a house may significantly drop or increase in value because of a new development nearby or the turn of a neighborhood to the worse or better. Or a single house may unexpectedly develop subsidence issues - a common problem in many English local housing markets including the Greater London Area. There is no hedge for these idiosyncratic risk components and many of these risks cannot be adequately insured against either. It would therefore seem sensible for households, to the extent feasible, to minimize the various risks associated with the purchase of a home and, if the risks are judged too high, to put off the purchase of a home entirely and rent instead.

In this paper, we hypothesize that as households move farther away from their original residence, search in the destination housing market becomes more difficult and more costly ${ }^{2}$, the amount and quality of information collected on the destination housing market and individual housing units decrease, and, therefore, purchase decisions become more risky as the future sales price becomes more uncertain.

\footnotetext{
1 Transaction costs include real estate transfer taxes (in the UK, for example, the Stamp Duty Land Tax ranges from 0 to $7 \%$ of the house value, depending on the transaction price), estate agent and legal costs (such as deed registration fees), search costs (including the costs of conducting a property survey), physical moving costs and psychological costs. Transaction costs vary enormously by country. According to the European Mortgage Federation (2006) the total transaction costs (more narrowly defined, so e.g. excluding search costs or psychological costs and not fully taking account of estate agent fees and some legal costs) range anywhere between 2 and 17\%, depending on the country considered. In Southern European countries such as Greece, Italy and Spain and in Belgium the transaction costs are particularly high, taking all costs into account far exceeding $10 \%$ of the purchase price. Haurin and Gill (2002) estimated the transaction costs of selling a home in the US to be in the order of $3 \%$ of the house value plus $4 \%$ of household earnings.

2 The emergence of the Internet may have substantially reduced such costs, but still a site (and neighborhood) inspection in person is essential for properties, unlike mass produced goods sold online and hence costs of travels for viewing are inevitable. Moreover, reliable information on individual properties, sites and neighborhoods and future developments in those neighborhoods typically require more than just a single visit; they require in-depth knowledge of the local area and the site that can only be accumulated over time.
} 
The difficulty of search largely arises from the heterogeneity of housing and neighborhood in terms of their characteristics and their location. A homebuyer is arguably more likely to make an ill-informed investment decision in a remote destination market by either paying too high a price (not being fully aware of some problems with the property, the site, the neighborhood, or future developments in the area that may adversely affect the value of the property) or buying into the 'wrong' neighborhood (mismatch). Renters may also misjudge the prevailing rent-level or choose the 'wrong' neighborhood in remote destination markets, but this has less grave consequences as, in contrast to owner-occupiers, renters do not have to bear the capital loss associated with the sale of a home plus they face much lower housing transaction costs and can therefore move more easily. ${ }^{3}$ Moreover, if say a neighborhood turns bad, this should, at least in the longer-run, also be reflected in lower subsequent rents or smaller rent increases, compensating the renter for the bad event occurring.

In an attempt to minimize investment risk, a reasonable strategy for a mover to a remote destination market would therefore seem to be to rent a property first and delay a home purchase until more (reliable) knowledge can be accumulated about the new neighborhood. As a consequence, we would expect that, all else held constant, households that move farther away from their original residence are less likely to own their next property than households that move nearby. This is the main proposition that we put to the data.

Our empirical analysis employs data from the Survey of English Housing (SEH). The SEH is a rich dataset that provides essential information such as the housing tenure status of households (the dependent variable), the distance moved (the key explanatory variable) and various demographic and socio-economic characteristics of households and household heads (the control variables). Controlling for demographic and socio-economic characteristics of mover households helps mitigate concerns of spurious correlation and omitted-variable bias. A crucial additional advantage of the SEH is that it provides information on the pre-move conditions of households. In particular, the tenure status at the previous accommodation helps control for unobservable preferences and the ability to own of households.

Our empirical analysis reveals three novel insights. Firstly, we provide evidence in favor of our proposed mechanism through which moving distance adversely affects the propensity to own: We demonstrate that the awareness of neighborhood problems such as crime, vandalism, litter and graffiti in the destination housing market decreases with the distance moved. We interpret this finding as indicating that movers do have difficulty in collecting information on distant housing markets and that they are therefore not fully aware of all the problems present in the relevant neighborhoods. Put differently, our implicit assumption is that the awareness of neighborhood problems is positively correlated with the amount and quality of information mover households have on the new neighborhood prior to the move.

Secondly, we provide evidence in favor of our main proposition that the propensity to own is

\footnotetext{
${ }^{3}$ In contrast to the relocation of homeowners, the relocation of renters does not trigger e.g. real estate transfer taxes. Moreover, estate agent and legal costs and also the search and physical moving costs are typically much lower for rental moves.
} 
adversely affected by the moving distance. We demonstrate that our findings are robust to controlling not only for demographic and socio-economic characteristics but also for region and survey year fixed effects, the previous housing tenure and housing characteristics, and dummy variables for the main reason of moving. Our analysis reveals that the negative effect is not only highly significant in a statistical sense but also reasonably meaningful in an economic sense. Based on our most rigorous specification, an increase in the distance moved by one standard deviation, measured at the mean, decreases the probability of owning of a representative household by 3.2 percentage points.

Thirdly, we test the proposition that the adverse effect of the distance moved on the propensity to own is of a temporary rather than permanent nature. We find that the length of stay at the destination market is adversely affected by the previous moving distance and this negative effect is stronger for private renters, consistent with the view that the optimal strategy for longer distance movers is to rent first and accumulate information on the destination housing market prior to making a momentous investment decision.

Our paper is structured as follows. In Section 2 we discuss the findings of previous related studies, clarify the contribution of our paper to the literature and derive empirically testable predictions. Section 3 describes the data, outlines our empirical strategy and presents our findings. The last section concludes.

\section{Background and testable hypotheses}

\subsection{Related research}

Our paper ties into a large literature on the determinants of the housing tenure (own-rent) decision. Most of the literature to date has focused on household specific characteristics - in our analysis controls - as determinants of the individual tenure choice. ${ }^{4}$

The focus of our paper is on the lack of knowledge on a destination housing market, which essentially refers to uncertainty about its various aspects. The seminal theoretical paper on the role of housing related risks for housing tenure decisions is Henderson and Ioannides (1983). Their housing investment-consumption model provides the basis for analyzing housing demand and tenure choice. The key element of their model is an investment constraint that requires that owner-occupiers must own at least as much housing as they consume, implying that typically homeowners have to 'overinvest' in housing. Fu (1991) further developed the framework and concluded that an increase in the investment risk (variation in house prices) should reduce the optimal housing investment. Consequently, an increase in investment risk should enlarge the distortion associated with owner-occupied housing. The greater distortion then leads to two effects: a reduction in housing consumption conditional on homeownership and a reduction in the attractiveness of homeownership relative to renting, implying a

\footnotetext{
${ }^{4}$ Factors such as basic demographic variables (e.g., Eilbott and Binkowski, 1985; Gyourko and Linneman, 1996), borrowing constraints (Linneman and Wachter, 1989), race (e.g., Kain and Quigley, 1972; Coulson, 1999; Gyourko et al., 1999; Painter et al., 2001; Hilber and Liu, 2008; Coulson and Dalton, 2010), expected length of stay (e.g., Haurin and Gill, 2002) and taxes (e.g., Rosen, 1979; Hilber and Turner, forthcoming) are major determinants of the individual housing tenure choice.
} 
reduced probability that households own their home (Hilber, 2005). ${ }^{5}$

On the empirical side, various studies have investigated the role of uncertainty for own-rent decisions. To begin with, Haurin and Gill (1987), Haurin (1991) and Robst et al. (1999) demonstrate, using US data, that income uncertainty adversely affects homeownership attainment. Diaz-Serrano (2005) reports a similar finding in a European context, where institutional settings and property market characteristics are quite different from the US. In a related study, Davidoff (2006) shows that individuals whose labor incomes co-vary strongly with housing values purchase relative inexpensive homes or rent.

More closely related to our paper, a number of studies (Rosen et al., 1984; Turner, 2003; Turner and Seo, 2007) find that the volatility of house prices adversely affects the propensity to own. In a similar vein, and consistent with our findings, Hilber (2005) provides evidence that greater neighborhood specific uncertainty significantly reduces the likelihood that households own their home and that this effect may be causal.

A few studies focus on the trade-off between the uncertainty of renting and house price uncertainty. Sinai and Souleles (2005) argue that with renting, the long-term cost of obtaining housing is unknown. Their empirical findings suggest that the rent hedging benefit associated with owner-occupied housing in the US significantly increases the homeownership rate. In a follow-up study (Sinai and Souleles, 2013) they point out that existing homeowners may also be protected from price fluctuations if they move within the same market or even between two markets, to the extent that the covariance in house prices between the two markets is high. This hedging argument should apply less though for neighborhood specific uncertainty since renters are compensated for shocks to neighborhoods with corresponding adjustments in rents (Hilber, 2005) and it should not apply to idiosyncratic risk components that are arguably more relevant in our empirical analysis.

A different strand of the literature focuses on the role of general knowledge on housing transactions and how such knowledge affects tenure decisions, e.g. through an intergenerational transfer of knowledge (Henretta, 1984; Boehm and Schlottman, 1999; Mulder and Smits, 1999; Dietz and Haurin, 2003; Haurin and Morrow-Jones 2006). What this literature reveals is that information likely plays a role for housing tenure decisions. Yezer and Thurston (1976) and DaVanzo (1983) argue that the longer the distance of a move, the more costly it is to obtain information on employment opportunities in the new labor market.

\footnotetext{
5 While Henderson and Ioannides (1983) and Fu (1991) omit risky assets other than housing, Brueckner (1997) provides a formal analysis of the 'overinvestment' issue of owner-occupied housing in a framework with several risky assets including owner-occupied housing. Using a combination of the housing investment-consumption model of Henderson and Ioannides (1983) and the standard mean-variance portfolio framework (Fama and Miller, 1980), Brueckner (1997) demonstrates that when the investment constraint induced by owner-occupied housing is binding, homeowners cannot adequately diversify their portfolio. Consequently, since the portfolio distortion is greater in places with higher housing risk (holding the level of housing consumption constant) and since a larger distortion leads to a decrease in the attractiveness of homeownership relative to renting, it follows that housing units in risky neighborhoods should be less likely to be owner-occupied (Hilber, 2005). The same conclusion can also be derived from a model that analyzes the tenure choice of households in a dynamic framework and under uncertainty of income and housing costs (Ortalo-Magné and Rady, 2002).
} 
Their findings arguably also apply to the housing market and to the extent this is the case, our prediction is that the longer the distance a household moves, the lower is the likelihood of homeownership through its negative effect on the amount and quality of the collected information on local housing markets.

To sum up, various types of uncertainty have been shown to lower the likelihood of homeownership and hence it can be inferred that lack of information or knowledge on local housing markets, which increases the uncertainty about housing investments in those markets, is also likely to discourage homeownership. Since house prices are strongly affected by location specific characteristics, knowledge on local housing markets may thereby have a greater impact on the homeownership decision than general knowledge of the process of buying a home. To our knowledge, the effect of the former type of knowledge has not been explored rigorously so far. The most closely related study to ours is Clark and Huang (2004) who look at the relationship between the distance moved and the homeownership status using the British Household Panel Survey. They suggest that homeowners do not show a particularly strong tendency to return to renting even after they make long-distance moves but their conclusion is based solely on descriptive statistics. This paper is the first study to test our main hypothesis formally in a rigorous way through an econometric approach.

\subsection{Testable predictions}

The amount of information obtained on new housing and neighborhoods is likely to decrease with the distance moved as previously argued by e.g. Yezer and Thurston (1976) or DaVanzo (1983). In terms of empirical prediction we would expect that the awareness of neighborhood problems in the destination housing market decreases with the distance moved, since movers have difficulty collecting reliable information on the problems - especially less apparent ones such as property crime or occasional vandalism - in more distant housing markets. We can formulate our first testable prediction as:

Prediction 1: The awareness of neighborhood specific problems decreases as the distance moved increases.

In the new housing markets, the movers face uncertainty about the quality of the neighborhood and the appropriate price level for housing of a given quality. This uncertainty is expected to encourage movers to opt to rent since renting implies no house price risk (which can be substantial for poorly informed buyers) and lower subsequent moving costs. Yet, the degree of uncertainty is expected to increase with the distance moved as the collection of information on the new housing market becomes increasingly difficult. Hence, our main prediction can be formulated as:

Prediction 2: The longer the distance moved the more likely households are to choose private renting over owner-occupation.

After settling down in the new accommodation, the level of the mover's knowledge of the local area is expected to gradually increase over time. We would therefore expect a corrective or adjustment move to more permanent owner-occupied accommodation nearby, as soon as 
the mover household has been able to accumulate sufficient information and thus reduce the investment risk in the local market. The tendency to adjust housing quality and microlocation within the same housing market sooner rather than later should be stronger for longer-distance movers as they are less likely to be satisfied with their first accommodation in the new market due to the informational shortage. We can formulate our third prediction as:

Prediction 3: The longer the distance moved the more likely households are to move again shortly after the initial move.

Through testing Predictions 1 to 3, we aim to demonstrate that facing uncertainty regarding the quality and conditions of new housing and neighborhoods, a long-distance mover's rational behavior may be to first move into temporary private rental accommodation and then later settle into a more permanent owner-occupied place.

\section{Empirical analysis}

\subsection{Data}

The data for our empirical analysis comes from the Survey of English Housing (SEH) provided by the UK Office of National Statistics. The SEH ran for fifteen years from 1993/94 until 2007/08 and covered close to 30,000 English households annually. ${ }^{6}$ The SEH provides the essential information for our analysis, including the household's housing tenure status (owner-occupier, private renter or public renter), the distance moved, scores of self-assessed problems in the household's neighborhood, housing-related characteristics, and demographic and socio-economic characteristics of households and their heads. An important feature of the survey is that, although it is cross-sectional in nature, it provides inter-temporal information on the households, allowing us to track the circumstances of a household over two time periods including, how the distance between the past and contemporaneous residential location affects the contemporaneous housing tenure choice. Of the inter-temporal information, the previous tenure status is particularly helpful in that it allows us to control for household preferences and a household's ability to own - both are not usually observed directly in survey data. Our regression sample consists of data from all 15 survey years. The resulting large sample size allows us to carry out additional tests for various sub-samples. The unit of observation is the household but the survey also provides personal information on the household heads. ${ }^{7}$

The SEH provides detailed information on a household's housing tenure status. Three main groups can be distinguished: homeowners, private renters, and public renters. ${ }^{8}$ The focus of

\footnotetext{
${ }^{6}$ The SEH ended in 2007/8 and was merged with the English House Condition Survey to form a single housing survey for the UK called the English Housing Survey. To ensure the continuity and consistency of the variables, we only use the SEH for our analysis.

${ }^{7}$ The SEH defines a 'household head' or 'household reference person' as a person in whose name the accommodation of the household is owned or rented.

${ }^{8}$ The group of 'homeowners' includes households that 'own outright', 'own with a mortgage', and 'partly own/partly rent'. The group of 'public renters' includes households that 'rent from local council or housing association'. The group of private renters includes households that 'rent from private landlords, property companies, employers, organizations or relatives and friends'.
} 
our empirical analysis is on the choice between owner-occupation and private renting. The inclusion of public renting in our analysis, as a tenure choice, would be problematic because in England public rental accommodation is allocated in a complex administrative process, based on formal criteria (income level and number of children). Unlike the own vs. private rent decision, it is not the outcome of households' cost-benefit considerations under uncertainty. ${ }^{9}$ We therefore exclude public renters from our analysis.

The main explanatory variable in our various estimating equations is the distance between the previous (original) and the current (destination) accommodation, as self-assessed by the moving households. The variable is reported in the SEH as a categorical variable with 8 groupings, ranging from 'under 1 mile' to '50 miles or more'. We exclude households that migrated from Northern Ireland or abroad $^{10}$ and converted the original variable to a continuous variable by taking the mid-value of each range ${ }^{11}$. The conversion facilitates the interpretation of our empirical results and allows us to estimate specifications with interaction terms between distance moved and other characteristics of households.

The control variables can be grouped into demographic and individual-specific characteristics of household heads, household characteristics, housing characteristics, and survey year and region dummies. We exclude two groups of household heads from our analysis. Firstly, we drop the 601 students in the sample. Students usually leave their family for college or university, so for a relatively short period of time, they live independently from their parents, and they become heads of their own households. Students in the UK typically move long distance rather than locally and they almost always rent their accommodation. Their housing tenure is determined mainly by the short expected length of stay. We also exclude 1,337 households that report that the main reason for moving is their intention to become homeowners out of concern of reversed-causation. ${ }^{12}$

The total number of households available for the entire duration of the survey is 429,878 . Our sample size is significantly smaller since the information on the distance moved is only available for those households that moved within 3 years of the time of the survey being

\footnotetext{
${ }^{9}$ Of the many characteristics of private renting, our analysis focuses on its ability to offer easy and quick access to and exit from accommodation without much financial commitment/investment risk. Whereas private renters in England typically have short expected durations in their accommodations and little financial commitment, public renters normally have very long expected stays and potentially a lot to lose from exiting. This is because public rental housing in England is strongly subsidized, characterized by 'undersupply' and, hence, long waiting lists. Unlike the own-rent decision of higher income households, which is arguably driven by cost-benefit considerations under uncertainty, low income households with many children will almost certainly opt for subsidized public rental housing if given the option (often after many years waiting in a queue).

${ }^{10}$ Households that moved from Northern Ireland or abroad are excluded from the regression sample as they are likely to choose private renting mainly because they are unfamiliar with the institutional settings of the English property and mortgage markets, rather than because they do not have knowledge of the local areas where they have settled down (the theoretical mechanism we explore in our analysis).

11 For example, 0.5 miles for the category of 'under 1 mile', 1.5 miles for ' 1 mile but not 2 miles', 3.5 miles for ' 2 miles but not 5 miles', etc. For the category of 'over 50 miles', we assigned ' 75 miles' arbitrarily. However, choosing other arbitrary values such as 50 or 100 miles leaves our results virtually unchanged.

12 The inclusion or exclusion of either of the two groups or both groups does not alter our findings. The estimated adverse impact and significance levels of the distance moved on the propensity to own - our main finding - are virtually unaffected.
} 
conducted, meaning they were relatively recent movers. This reduces the sample size to 67,648. We further drop public renters, foreign migrants, students and those households that moved 'for homeownership', reducing our sample to 44,489 households. Finally, households are dropped if they have missing values in any of the variables, leaving us with a sample size of 37,755 observations. The summary statistics for this sample are reported in Table 1. Starting from this number of observations, the exact sample size used to test Predictions 1 to 3 varies somewhat due to the exclusion of some observations, depending on the specification estimated, as discussed below.

\subsection{Empirical strategy}

Prediction 1 is concerned about the relationship between the distance moved and the level of information that the movers hold on the new neighborhood. The SEH provides information on how household heads think about the severity of local problems such as crime. Our expectation is that households who move a longer distance and therefore have less information on the destination neighborhood will be unaware of many micro-location specific problems and will therefore underestimate these problems. The mover's assessment of the local problems is of course not only affected by the distance moved, but also by the easily observable severity of the problems/quality of the neighborhood. If easily observable neighborhood quality were correlated with the distance moved but omitted from the regression, then the estimated coefficient on the distance moved variable would be biased. This could be, for example, because households may want to move away from local problems through long distance moves.

As the SEH does not provide any direct information on neighborhood quality, our strategy is to indirectly control for neighborhood quality - to the extent feasible - by including variables in our empirical specification that are likely to be strongly related to neighborhood quality such as real household income and house value council tax bands. Real household income is well-known to be strongly positively associated with neighborhood quality due to the fact that the higher the income, the more likely the household is to live in a good neighborhood. Local house values also have a close relationship with neighborhood quality through the process of house price capitalization (see Hilber, 2012, for a synthesis of the recent literature). In our empirical specifications we use the local house value council tax band as a proxy for local house values. Council tax bands do not precisely measure the capitalized value of the current neighborhood quality; rather they represent the 'sustained' neighborhood quality as assessed by local Council officials. ${ }^{13}$ House value council tax bands can be considered to be a noisy but exogenous assessment of the neighborhood quality. Importantly, they do not represent a subjective assessment by the survey respondent. Finally, the physical size of housing units - as measured e.g. by the number of bedrooms - is likely related to the quality

\footnotetext{
${ }^{13}$ House value council tax bands are determined by the local Council - the local jurisdictions in England based on the characteristics of the property, the site, and the location. Survey respondents have no influence over the house value council tax band. The tax bands do not represent current house values but historic values that broadly reflect the capitalized value of the quality of the neighborhood (at least within a city). Council tax bands change rarely and survey year fixed effects should capture any year specific (space-invariant) unobserved effects.
} 
of the neighborhood. Large (and expensive) houses are found more often in high-quality neighborhoods.

Our expectation is that, holding household characteristics and the neighborhood quality constant and controlling for the survey year, longer distance movers will self-report lower severities of neighborhood problems in the destination housing market. Specifically, we can test Prediction 1 by estimating the following equation:

$$
\begin{aligned}
& \text { Subjective assessment of severity of local problem } \text { lijt }_{1}=\alpha_{0}+\alpha_{1}{\text { distance } \text { moved }_{i}} \\
& +\alpha_{2} \text { controls }_{i}+\alpha_{3} \text { controls }_{j}+\alpha_{4} D_{t}+\varepsilon
\end{aligned}
$$

whereas $i, j$, and $t$ denote the household/head, location/property ${ }^{14}$, and survey year respectively.

The dependent variable takes one of the following three values: a specific local problem, for example, crime is 'serious' (value $=1$ ), 'problematic but not serious' (value $=2$ ), or 'not a problem at all' (value $=3$ ). Since a lower value of the dependent variable indicates greater severity, holding all else constant, Prediction 1 implies that $\alpha_{1}$ should be positive.

Estimating an ordered logit model is appropriate here, as only an order among the options of the dependent variables is known. To check whether Prediction 1 finds support in the data for different types of local problems, we investigate the cases of crime, vandalism, litter and graffiti.

Prediction 1 suggests that, holding the neighborhood quality constant, the extent to which a mover household is aware of neighborhood problems in the destination market at the time of the tenure decision should decrease with the distance moved. Hence, in order to accurately test Prediction 1, ideally, we would use the self-assessment of neighborhood problems at the point in time of the housing tenure decision. However, this information is not available in the SEH. As a second best alternative, we limit our regression sample only to mover households that, at the time of the survey interview, had lived in their current accommodation for a short period of time. We therefore drop all households from the regression sample that have lived in their current home for one year or more and only keep the most recent movers (henceforth, 'recent movers'). Our rationale for choosing a one year window is that while households start accumulating information on the destination neighborhood as soon as they move in, it would seem reasonable to assume that it takes some time - a year or more rather than just weeks or a few months - to fully comprehend the nature and complexity of the neighborhood, likely development plans, and accumulated social capital etc. To the extent that households accumulate all relevant information nearly instantaneously (within weeks or months) we would expect not to find a significant positive coefficient $\alpha_{1}$. Out of the sample of 37,755 observations - reported in Table $1-15,202$ had lived in their locations for less than one year.

\footnotetext{
${ }^{14}$ Location refers to the site, neighborhood, and region. Location-specific variables include: the house value council tax band and the region fixed effects. Property-specific variables include the number of bedrooms and the accommodation type.
} 
In addition, the regression sample size varies depending on the type of neighborhood problem considered. For example, for crime the sample size is 10,543 households. Table 1 provides more detail.

Our main research objective is to test whether, holding other things constant, the distance moved affects the mover's decision whether to own or rent privately. We specify the regression model such that the probability of homeownership is expressed as a function of the distance moved along with other controls. Our main estimating equation can be expressed as:

$$
\operatorname{Pr}\left(\text { own }_{i j t}\right)=\beta_{0}+\beta_{1} \text { distance moved }_{i}+\beta_{2} \text { controls }_{i}+\beta_{3} \text { controls }_{j}+\beta_{4} D_{t}+\vartheta
$$

whereas $i, j$, and $t$ again denote the household/head, location/property, and survey year respectively.

The dependent variable is a dummy that takes the value of 1 if a household is an owneroccupier or 0 if it rents from a private landlord. The model is estimated by maximum likelihood logit. Our main Prediction 2 implies that the estimated coefficient of the distance moved $\left(\beta_{1}\right)$ should take a negative sign.

One set of household-specific control variables appears uniquely in estimating equation (2): dummy variables for the tenure status of household $i$ in the previous accommodation. Specifically, we include two dummy variables, one for public renters and one for private renters (owner-occupiers are the omitted category). The past tenure status is likely correlated with both the current tenure status and the distance moved. Previous homeowners tend to become homeowners again and are arguably more reluctant to move short distances as substantial moving costs cannot be justified for short-distance moves.

In order to test Prediction 2, we again confine the regression sample to 'recent movers'. We are interested in the relationship between the distance moved and the housing tenure status at the time of the move. We expect that the negative link between distance moved and homeownership will be diluted over time, as long-distance movers, who are more likely to be renters, are expected to move again at a faster rate than short-distance movers. The sample of 'recent movers' again includes 15,202 households. When the cases with missing values relating to the previous tenure variable are dropped, the final sample size for the regressions is 13,185 .

Prediction 3 states that the longer the distance moved, the more likely movers are to make an adjustment move shortly after the initial move. If this is true, the proportion of residents with lengthier stays should be lower among the longer-distance movers than among the shorterdistance ones. We can test this prediction by estimating the following estimating equation:

$$
\begin{aligned}
& \text { Length of } \text { stay }_{i j t}=\gamma_{0}+\gamma_{1} \text { distance moved }_{i}+\gamma_{2} \text { controls }_{i}+\gamma_{3} \text { controls }_{j} \\
& +\gamma_{4} D_{t}+\mu
\end{aligned}
$$

whereas $i, j$, and $t$ again denote the household/head, location, and survey year respectively. The dependent variable is the length of stay in the current accommodation. It is given as a 
categorical variable taking one of the following three values: 'less than 1 year', ' 1 year but not 2 years' and ' 2 years but not 3 years'. The reason for why the length of stay (the dependent variable) does not go beyond 3 years is because the information on the distance moved (the key explanatory variable) is only available for those who have lived in the current accommodation for less than 3 years. The categorical dependent variable is converted into a continuous variable by taking the mid-value of the range (e.g. half a year for 'less than 1 year'). Since the transformed variable is continuous, we use OLS to estimate equation (3). Prediction 3 suggests that the estimated coefficient $\gamma_{1}$ on the distance moved variable should have a negative sign.

The set of other control variables is similar to those used in equations (1) and (2). The dummy variables capturing the housing tenure status are particularly important, as private renters are more likely to move again soon and also to have moved longer distances than homeowners. Unlike in the previous specifications, testing Prediction 3 does not require the regression sample to be limited to recent movers, as the length of stay is the main explanatory variable. All 37,755 observations are used. Table 1 reports the summary statistics.

\subsection{Empirical results}

Table 2 reports the ordered logit regression results for Prediction 1 that the awareness of neighborhood specific problems decreases as the distance moved increases (i.e., the proposed mechanism that we argue is driving long-distance movers to rent rather than own). (Table 2 only reports the coefficients of the key variable 'distance moved'. We report the full set of results with all controls in Table A1 in an unpublished Web-Appendix.) The dependent variable in columns (1) to (4) is a measure that captures how serious household heads think crime is in their local areas. Since a smaller value of the measure indicates a more serious problem, we would expect that the coefficient on the distance variable is positive.

Column (1) reports findings for a specification that only includes the distance moved plus regional and time dummies. The estimated coefficient (0.0053) turns out to be positive and significant at the $1 \%$ level, consistent with Prediction 1 . However, the coefficient could be biased due to omitted variables. When household heads' personal and household characteristics are additionally controlled for in column (2), the estimate for the distance moved remains statistically significant at the $1 \%$ level but goes down somewhat (0.0045) and arguably becomes less. This is not surprising since various demographic and socio-economic characteristics are correlated with the distance moved. Though not explicitly shown, the addition of real household income contributes most strongly to the decline of the estimated coefficient on 'distance moved', consistent with our reasoning above. In column (3) we additionally control for housing characteristics. Adding the various housing controls reduces the coefficient on 'distance moved' further to 0.0041 . Though again not shown explicitly, the housing value control derived from council tax bands, contributes most strongly to the drop in the coefficient on 'distance moved'. Lastly, as shown in column (4), when the main reason for moving is also controlled for, the estimate of interest decreases further to 0.0034 . However, even after carefully controlling for a large set of covariates in column (4), the 
estimated coefficient of the distance moved still remains positive and remains highly statistically significant at the $1 \%$ level. In columns (5) to (7), we report the same regression result as that reported in column (4), but with alternative dependent variables: seriousness of vandalism, graffiti and litter. Again, smaller values of the measures indicate more serious problems, so we would again expect that the coefficient on the distance variable is positive in all cases. Though the results vary somewhat depending on the outcome measure, the estimates of the distance moved variable are positive and statistically significant, at least at the $10 \%$ level, throughout. All the results are consistent with the hypothesis that the distance moved does have a negative effect on the level of information that movers hold on destination housing markets.

Table 3 documents the results of logit estimates for Prediction 2 (the main proposition), which states that the longer the distance moved, the lower is the probability that a household becomes an owner-occupier. Again, Table 3 only reports the key findings; the full set of results is reported in the unpublished Web-Appendix Table A2. The explanatory variables that are thought to be correlated with both the distance moved and the probability of homeownership are grouped into three categories and controlled for gradually, from left to right. In all columns, the distance moved has a negative relationship with the probability of homeownership, consistent with Prediction 2, and in all specifications the estimated effect is statistically significant at the $1 \%$ level. The estimates for the distance moved vary substantially depending on the types of control variables included in the empirical model. When personal, household and housing characteristics are controlled for in columns (2) and (3), the negative relationship between distance moved and the probability of homeownership becomes substantially stronger (0.011 and 0.014 compared to 0.0053 in column 1$)$.

However, when we add controls for 'the main reasons for moving', the coefficient drops again to 0.0054 . The explanation for this drop is the fact that the reasons for moving are correlated with the distance moved. Those who want to move for job-related reasons (often for better job opportunities in large labor markets such as London) need to move long distances whilst those moving for housing- or neighborhood-related reasons move short distances. ${ }^{15}$ The average distance moved for housing-related movers in the regression sample used in Table 3 is 5 to 6 miles, for neighborhood-related movers it is 13 to 17 miles and for job-related movers it is about 50 miles. At the same time, the reasons for moving are also correlated with the homeownership status. Housing- and neighborhood-related movers tend to owner-occupy their new homes, whereas the job-related movers tend to rent, regardless of the distance moved. One explanation for this is that, in contrast to housing- and neighborhood-related movers, the prime focus of job-related movers is on their new jobs rather than on finding a permanent place to live in. In fact, this is another piece of evidence that the information available on the local housing market has an influence on movers' housing tenure decisions. Overall, the reasons for moving are correlated with both, the distance moved and the tenure decision, and controlling for the reasons substantially reduces

${ }^{15}$ See also Hilber and Lyytikäinen (2013) for more evidence on this in the context of the existence of the UK Stamp Duty Land Tax and for further implications. 
the strength of the negative correlation between them. However, the correlation is still negative and significant at the $1 \%$ level, consistent with Prediction 2.

Another, potentially important, factor determining the housing tenure status is the degree to which a household is financially constrained (e.g., Linneman and Wachter, 1989). In a hypothetical setting where all households are severely financially constrained, nobody would own and the distance moved would be unrelated to homeownership. Therefore, the more financially constrained households are, the more biased towards zero the relationship between the distance moved and homeownership can be expected to be.

The SEH, like most other household datasets, does not include household wealth, a measure for how down-payment constrained households are. However, the dataset does include information on the previous housing tenure status; and therefore, by implication, on whether households have collateral (i.e., a home), the proceeds (capital gains) of which they can use to purchase a home in a subsequent move. Moreover, previous homeowners are also better placed to obtain a new mortgage. Therefore, previous homeowners' contemporaneous tenure decisions can be expected to be less likely affected by financial constraints than those by previous renters and, hence, the effect of the distance moved on the contemporaneous propensity to own can be expected to be less biased towards zero. Indeed, the interaction effects between different types of previous housing tenure (homeowner, private renter and public renter), reported in column (1) of Table 4, reveal that the distance moved only affects the contemporaneous tenure choice at the destination location of previous homeowners but not of previous private renters or social renters. ${ }^{16}$ Another implication from this finding is that informational constraints also matter for those who are wealthy enough to afford homeownership (possibly even outright). Even if households want to and are able to own, uncertainty about the value of a potential investment induced by lack of reliable information likely discourages homeownership. Overall, these results provide further indication that lack of housing and neighborhood information are very important for housing tenure decisions.

Similar to the previous tenure status, household income also likely captures the ability of households to afford homeownership, as it reflects the degree to which households are liquidity constrained. Hence, in a similar vein, in column (2) of Table 4 we examine whether the relationship of interest varies among different income groups. Our prediction is that the higher the household income, the less likely households are financially constrained and, therefore, the more negative should be the estimated effect of the distance moved on the propensity to own. There are four levels of household income in our data: ' $£ 0$ to $£ 9,999$ '; ' $£ 10,000$ to $£ 19,999$; ' $£ 20,000$ to $£ 49,999$ ', and; ' $£ 50,000$ and over'. Using the interaction terms between the different income groups on the one hand and the distance moved on the other hand, we thus estimate for each income group separately the effect of the distance moved on the propensity to own. The empirical results are again consistent with our prediction; the lowest income group indeed has the smallest estimate (with a positive sign)

16 Table 4 reports only the coefficients and standard errors for the key interaction effects. For the full set of results we refer the interested reader to the unpublished Web-Appendix Table A3. 
and it is not statistically different from zero, while the top income group has the largest and the most statistically significant negative estimate. The result provides further indication that households can express their preference over residential tenure types according to the distance moved only when they are not severely financially constrained.

As discussed above, the main reasons for moving are correlated with the intensity of the search in the destination housing markets. Those households that want to move for housing and neighborhood related reasons can be expected to search more intensely than those that move for job-related reasons, regardless of the distances they plan to move. Therefore, the relationship between the propensity to own and the distance moved is expected to be weaker and less significant for housing- and neighborhood-related movers. We test and confirm this hypothesis using the interaction terms between the distance moved and the reasons for moving and report results in column (3) of Table 4. The estimates for 'distance $\times$ neighborhood' and 'distance $\times$ housing' are positive but not statistically different from zero, while the coefficients on the remaining interaction effects/reasons ('distance $\times$ had to move'; 'distance $\times$ personal/family reasons'; 'distance $\times$ job-related reasons') are all negative and significant. Of these, the estimate for the job-related movers is the most negative, implying that the job-related movers' propensity to own is more strongly adversely affected by the distance moved than that of any other group of movers.

Table 5 reports quantitative effects of the relationships of interest based on the various regression results reported in Tables 3 and 4. The first row reveals that, according to the core specification in Table 3, column (4), a one standard deviation increase in the distance moved from its mean, reduces the probability of being a homeowner by $3.2 \%$ points. This suggests that the impact of the distance moved on homeownership is quantitatively reasonably meaningful.

The remaining rows in Table 5 report quantitative interpretations of the various estimated interaction effects. Panel A reveals that a one standard deviation increase in the distance moved reduces the propensity of a previous homeowner to own again by $6.1 \%$ points, a quantitatively quite meaningful effect. Similarly, as Panel B documents, a one standard deviation increase in the distance moved reduces the propensity to own of a household with earnings of ' $£ 50,000$ or more’ by $8.6 \%$ points. Finally, Panel $\mathrm{C}$ suggests that a one standard deviation increase in the distance moved reduces the propensity to own of a job related mover by $8.4 \%$ points.

Table 6 finally reports OLS regression results of the test of Prediction 3, which states that the longer the distance a household has moved, the more likely it is to move again soon to find more permanent accommodation within the same housing market. As discussed in Section 3.2, our empirical strategy is to run OLS regressions with the dependent variable being the length of stay in the current location and the main explanatory variable being the distance moved. The coefficient on the distance moved variable is expected to be negative. Column (1) in Table 6 reports results for a specification that only includes the distance moved plus time and 
region dummies. ${ }^{17}$ The estimate of the distance moved on the length of stay is indeed negative and statistically different from zero with 99\% confidence, implying that longerdistance movers move again at a faster rate than their shorter-distance counterparts. This result is persistent and the coefficient on the distance moved variable becomes slightly larger when additional controls are added. Columns (2) and (3) of Table 6 provide details. Lastly, we would expect that the effect of interest is stronger among private renters. This is because those who do not yet live in permanent accommodation but plan to move to more permanent accommodation will likely be private renters in the first place. Therefore, the estimated effect of the distance moved on the length of stay should be more negative for private renters. Column (4) of Table 6 provides evidence consistent with this prediction. Though the effect is smaller for homeowners, it is worth noting that even homeowners tend to stay for a shorter period, the longer the distance they had moved previously. This latter finding is consistent with two different interpretations: (1) long distance movers may generally be more mobile and (2) long distance movers are more likely to make ill-informed housing decisions that result in mismatch and, as a consequence, homeowners may be more likely to re-adjust their housing choice despite the fact that this triggers a capital loss, stamp duty payments, and other transaction costs. Having said all this, the fact that the distance moved effect is about twice as strong for private renters, provides support for our main proposition that long distance moves, as a consequence of information decay, discourage households to own.

\section{Conclusion}

Previous research found that housing investment risk has a significant adverse impact on the decision of households to own. In this paper we explore the link between the distance moved, the corresponding information decay and increased investment risk, and the subsequent propensity of households to buy rather than rent their home. Our key findings can be summarized as follows: An increase in the distance moved reduces the amount and/or quality of information households have on the destination housing market. This in turn increases the housing investment risk in the destination market (although we cannot explicitly show this link in our empirical analysis) and thereby reduces the propensity to own - our main empirical finding. This adverse effect on homeownership is not permanent however. Households that moved a longer distance, especially private renters, are more likely to have a shorter stay in their home compared to households that moved a shorter distance. This implies that those long-distance movers who were discouraged to buy in the destination market, as a consequence of the distance induced investment risk, start accumulating information on the local property market and specific sites as soon as they move to the new area. This in turn lowers their investment risk over time and encourages them to consider making a more permanent 'corrective' move locally with the intent to buy a home.

Overall, our empirical findings suggest that information gathered on local housing markets has an important adverse effect on the propensity of a household to own: The difficulty of

17 Table 6 only reports the key results. However, the full set of results including coefficients and standard errors for the control variables is documented in the unpublished Web-Appendix Table A4. 
collecting information on the destination housing market discourages homeownership. More generally, this finding may at least partially explain why immigrants (who move very long distances and have least information on the destination housing market) tend to have lower homeownership propensities, even when controlling for numerous other factors that drive housing tenure decisions. Conversely, it can be argued that a well-functioning private rental housing market for temporary accommodation serves (at least) two important purposes: it prevents ill-informed housing purchases that can only be reversed with a significant financial loss and, since long-distance movers typically move for job-related reasons, it facilitates matching in the labor market. 


\section{References}

Boehm, T. and A. Schlottman. 1999. Does Homeownership by Parents Have an Economic Impact on their Children? Journal of Housing Economics 8: 217-232.

Brueckner, J.K. 1997. Consumption and Investment Motives and the Portfolio Choices of Homeowners. Journal of Real Estate Finance and Economics 15: 159-180.

Clark, A.V. and Y. Huang. 2004. Linking Migration and Mobility: Individual and Contextual Effects in Housing Markets in the UK. Regional Studies 38: 617-628.

Coulson, N.E. 1999. Why are Hispanic- and Asian-American Homeownership Rates So Low? Immigration and Other Factors. Journal of Urban Economics 45: 209-227.

Coulson, N.E. and M. Dalton. 2010. Temporal and Ethnic Decompositions of Homeownership Rates: Synthetic Cohorts across Five Censuses. Journal of Housing Economics 19: 155-166.

DaVanzo, J. 1983. Repeat Migration in the United States: Who Moves Back and Who Moves on? Review of Economics and Statistics 65: 552-559.

Davidoff, T. 2006. Labor Income, Housing Prices, and Homeownership. Journal of Urban Economics 59: 209-235.

Diaz-Serrano, L. 2005. Labor Income Uncertainty, Skewness and Homeownership: A Panel Data Study for Germany and Spain. Journal of Urban Economics 58: 156-176.

Dietz, R.D. and D.R. Haurin. 2003. The Social and Private Micro-Level Consequences of Homeownership. Journal of Urban Economics 54: 401-450.

Eilbott, P. and E. Binkowski. 1985. The Determinants of SMSA Homeownership Rates. Journal of Urban Economics 17: 293-304.

European Mortgage Federation. 2006. Study on the Cost of Housing in Europe. Brussels: EMF.

Fama, E.F. and M.H. Miller. 1980. The Theory of Finance. Hinsdale, IL: Dryden Press.

Fu, Y. 1991. A Model of Housing Tenure Choice: Comment. American Economic Review 81: 381-383.

Gyourko, J. and P. Linneman. 1996. Analysis of the Changing Influences on Traditional Households' Ownership Patterns. Journal of Urban Economics 39: 318-341.

Gyourko, J., P. Linneman and S. Wachter. 1999. Analyzing the Relationships among Race, Wealth, and Home Ownership in America. Journal of Housing Economics 8: 63-89.

Haurin, D.R. 1991. Income Variability, Homeownership, and Housing Demand. Journal of Housing Economics 1: 60-74.

Haurin, D.R. and H.L. Gill. 1987. Effects of Income Variability on the Demand for OwnerOccupied Housing. Journal of Urban Economics 22: 136-150. 
Haurin, D.R. and H.L. Gill. 2002. The Impact of Transaction Costs and the Expected Length of Stay on Homeownership. Journal of Urban Economics 51: 563-584.

Haurin, D.R. and H.A. Morrow-Jones. 2006. The Impact of Real Estate Market Knowledge on Tenure Choice: A Comparison of Black and White Households. Housing Policy Debate 17: 625-653.

Henderson, J.V. and Y. Ioannides. 1983. A Model of Housing Tenure Choice. American Economic Review 73: 98-113.

Henretta, J.C. 1984. Race Differences in Middle-Class Lifestyle: The Role of Homeownership. Housing Economics 1: 60-74.

Hilber, C.A.L. 2005. Neighborhood Externality Risk and the Homeownership Status of Properties. Journal of Urban Economics 57: 213-241.

Hilber, C.A.L. 2012. The Economic Implications of House Price Capitalization: A Synthesis. Mimeo, London School of Economics, September 2012.

Hilber, C.A.L. and Y. Liu. 2008. Explaining the Black-White Homeownership Gap: The Role of Own Wealth, Parental Externalities and Locational Preferences. Journal of Housing Economics 17: 152-174.

Hilber, C.A.L. and T. Lyytikäinen. 2013. Housing Transfer Taxes and Household Mobility: Distortion on the Housing or Labour Market? VATT Working Paper No. 47, August.

Hilber, C.A.L. and T.M. Turner. Forthcoming. The Mortgage Interest Deduction and its Impact on Homeownership Decisions. Review of Economics and Statistics.

Kain, J.F. and J.M. Quigley. 1972. Housing Market Discrimination, Home-Ownership, and Savings Behavior. American Economic Review 62: 263-277.

Linneman, P. and S. Wachter. 1989. The Impacts of Borrowing Constraints on Homeownership. Journal of the American Real Estate and Urban Economics Association 17: 389-402.

Mulder, C.H. and J. Smits. 1999. First-Time Home-Ownership of Couples - The Effect of Intergenerational Transmission. European Sociological Review 15: 323-337.

Ortalo-Magné, F. and S. Rady. 2002. Tenure Choice and the Riskiness of Non-Housing Consumption. Journal of Housing Economics 11: 266-279.

Painter, G., S. Gabriel and D. Myers. 2001. Race, Immigrant Status, and Housing Tenure Choice. Journal of Urban Economics 49: 150-167.

Robst, J., R. Deitz and K.M. McGoldrick. 1999. Income Variability, Uncertainty and Housing Tenure Choice. Regional Science and Urban Economics 29: 219-229.

Rosen, H.S. 1979. Housing Decisions and the U.S. Income Tax: An Econometric Analysis. Journal of Public Economics 11: 1-24.

Rosen, H.S., K.T. Rosen and D. Holtz-Eakin. 1984. Housing Tenure, Uncertainty, and 
Taxation. Review of Economics and Statistics 66: 405-416.

Sinai, T.M. and N.S. Souleles. 2005. Owner Occupied Housing as a Hedge against Rent Risk. Quarterly Journal of Economics 120: 763-789.

Sinai, T.M. and N.S. Souleles. 2013. Can Owning a Home Hedge the Risk of Moving? American Economic Journal: Economic Policy 5: 282-312.

Turner, T.M. 2003. Does Investment Risk Affect the Housing Decisions of Families? Economic Inquiry 41: 675-691.

Turner, T.M. and D. Seo. 2007. Investment Risk and the Transition into Homeownership. Journal of Regional Science 47: 229-253.

Yezer, A. and L. Thurston. 1976. Migration Patterns and Income Change: Implications for the Human Capital Approach to Migration. Southern Economic Journal 42: 693-702. 
TABLES

Table 1

Summary statistics

\begin{tabular}{|c|c|c|c|c|c|}
\hline Variable & Obs. & Mean & Std. Dev. & $\overline{\operatorname{Min}}$ & Max \\
\hline Homeowner & 37755 & 0.715 & 0.451 & 0 & 1 \\
\hline Distance moved & 37755 & 16.0 & 24.9 & 0.5 & 75 \\
\hline Length of stay (categories) & 37755 & 1.878 & 0.818 & 1 & 3 \\
\hline Age of HH head & 37755 & 38.8 & 13.2 & 16 & 95 \\
\hline Age squared of $\mathrm{HH}$ head & 37755 & 1682.1 & 1241.0 & 256 & 9025 \\
\hline Sex of HH head & 37755 & 1.259 & 0.438 & 1 & 2 \\
\hline \multicolumn{6}{|l|}{$\begin{array}{l}\text { Economic status of HH head } \\
\text { (Full-time employed excl.) }\end{array}$} \\
\hline Part-time employed & 37755 & 0.062 & 0.242 & 0 & 1 \\
\hline Unemployed & 37755 & 0.029 & 0.168 & 0 & 1 \\
\hline Retired & 37755 & 0.075 & 0.263 & 0 & 1 \\
\hline Inactive & 37755 & 0.060 & 0.237 & 0 & 1 \\
\hline \multicolumn{6}{|l|}{$\begin{array}{l}\text { Household composition } \\
\text { (Single excl.) }\end{array}$} \\
\hline Couple & 37755 & 0.653 & 0.476 & 0 & 1 \\
\hline Lone parent & 37755 & 0.081 & 0.273 & 0 & 1 \\
\hline Multi-family HH & 37755 & 0.040 & 0.195 & 0 & 1 \\
\hline No. of children & 37755 & 0.647 & 0.972 & 0 & 7 \\
\hline No. of adults & 37755 & 1.842 & 0.685 & 1 & 9 \\
\hline \multicolumn{6}{|l|}{ Real HH income } \\
\hline$£ 10,000-£ 19,999$ & 37755 & 0.289 & 0.453 & 0 & 1 \\
\hline$£ 20,000-£ 49,000$ & 37755 & 0.422 & 0.494 & 0 & 1 \\
\hline$£ 50,000$ or more & 37755 & 0.081 & 0.273 & 0 & 1 \\
\hline No. of bedrooms & 37755 & 2.702 & 0.989 & 1 & 10 \\
\hline \multicolumn{6}{|l|}{$\begin{array}{l}\text { Accommodation type } \\
\quad \text { (Detached/Bungalow excl.) }\end{array}$} \\
\hline Semi-detached & 37755 & 0.284 & 0.451 & 0 & 1 \\
\hline Terraced & 37755 & 0.291 & 0.454 & 0 & 1 \\
\hline Purpose-built flat & 37755 & 0.104 & 0.305 & 0 & 1 \\
\hline Converted flat & 37755 & 0.086 & 0.281 & 0 & 1 \\
\hline \multicolumn{6}{|l|}{$\begin{array}{l}\text { House value - council tax band } \\
\text { (Up to } 40 \mathrm{k} \text { excl.) }\end{array}$} \\
\hline Up to $£ 52 \mathrm{k}$ & 37755 & 0.196 & 0.397 & 0 & 1 \\
\hline Up to $£ 68 \mathrm{k}$ & 37755 & 0.219 & 0.414 & 0 & 1 \\
\hline Up to $£ 88 \mathrm{k}$ & 37755 & 0.195 & 0.396 & 0 & 1 \\
\hline Up to $£ 120 \mathrm{k}$ & 37755 & 0.107 & 0.309 & 0 & 1 \\
\hline Up to $£ 160 \mathrm{k}$ & 37755 & 0.054 & 0.226 & 0 & 1 \\
\hline Up to $£ 320 \mathrm{k}$ & 37755 & 0.040 & 0.195 & 0 & 1 \\
\hline Over $£ 320 \mathrm{k}$ & 37755 & 0.008 & 0.090 & 0 & 1 \\
\hline \multicolumn{6}{|c|}{$\begin{array}{l}\text { Main reasons for moving } \\
\quad \text { (Neighborhood-related excl.) }\end{array}$} \\
\hline Housing-related & 37755 & 0.295 & 0.456 & 0 & 1 \\
\hline Had to move & 37755 & 0.125 & 0.331 & 0 & 1 \\
\hline Personal/family-related & 37755 & 0.328 & 0.469 & 0 & 1 \\
\hline Job-related & 37755 & 0.120 & 0.325 & 0 & 1 \\
\hline \multicolumn{6}{|l|}{$\begin{array}{l}\text { Region } \\
\quad \text { (North East excl.) }\end{array}$} \\
\hline North West & 37755 & 0.123 & 0.328 & 0 & 1 \\
\hline Yorkshire \& the Humber & 37755 & 0.095 & 0.294 & 0 & 1 \\
\hline East Midlands & 37755 & 0.084 & 0.277 & 0 & 1 \\
\hline West Midlands & 37755 & 0.088 & 0.283 & 0 & 1 \\
\hline Eastern & 37755 & 0.120 & 0.325 & 0 & 1 \\
\hline London & 37755 & 0.129 & 0.335 & 0 & 1 \\
\hline South East & 37755 & 0.193 & 0.395 & 0 & 1 \\
\hline South West & 37755 & 0.120 & 0.324 & 0 & 1 \\
\hline
\end{tabular}


Table 1-Continued

\begin{tabular}{|c|c|c|c|c|c|}
\hline Variable & Obs. & Mean & Std. Dev. & Min & Max \\
\hline \multicolumn{6}{|l|}{$\begin{array}{l}\text { Year of survey } \\
\text { (1993 excl.) }\end{array}$} \\
\hline 1994 & 37755 & 0.050 & 0.218 & 0 & 1 \\
\hline 1995 & 37755 & 0.059 & 0.235 & 0 & 1 \\
\hline 1996 & 37755 & 0.060 & 0.238 & 0 & 1 \\
\hline 1997 & 37755 & 0.072 & 0.259 & 0 & 1 \\
\hline 1998 & 37755 & 0.084 & 0.278 & 0 & 1 \\
\hline 1999 & 37755 & 0.078 & 0.268 & 0 & 1 \\
\hline 2000 & 37755 & 0.080 & 0.271 & 0 & 1 \\
\hline 2001 & 37755 & 0.078 & 0.268 & 0 & 1 \\
\hline 2002 & 37755 & 0.075 & 0.263 & 0 & 1 \\
\hline 2003 & 37755 & 0.073 & 0.261 & 0 & 1 \\
\hline 2004 & 37755 & 0.069 & 0.253 & 0 & 1 \\
\hline 2005 & 37755 & 0.066 & 0.248 & 0 & 1 \\
\hline 2006 & 37755 & 0.061 & 0.240 & 0 & 1 \\
\hline 2007 & 37755 & 0.057 & 0.232 & 0 & 1 \\
\hline \multicolumn{6}{|c|}{ Assessment of neighborhood problems } \\
\hline Crime & 10543 & 2.495 & 0.657 & 1 & 3 \\
\hline Vandalism & 11594 & 2.634 & 0.593 & 1 & 3 \\
\hline Graffiti & 10360 & 2.779 & 0.483 & 1 & 3 \\
\hline Litter & 11689 & 2.586 & 0.640 & 1 & 3 \\
\hline \multicolumn{6}{|c|}{$\begin{array}{l}\text { Previous tenure } \\
\quad \text { (Homeowner excluded) }\end{array}$} \\
\hline Public renter & 13185 & 0.065 & 0.246 & 0 & 1 \\
\hline Private renter & 13185 & 0.406 & 0.491 & 0 & 1 \\
\hline
\end{tabular}

Note: The size of the regression samples varies depending on the predictions tested. See Section 3.2 for a detailed discussion. 
Table 2

Ordered logit regression on neighborhood problem awareness

(Dependent variable: Seriousness of crime, vandalism, graffiti, and litter in the area)

\begin{tabular}{|c|c|c|c|c|c|c|c|}
\hline & $\begin{array}{l}(1) \\
\text { Crime }\end{array}$ & $\begin{array}{l}(2) \\
\text { Crime }\end{array}$ & $\begin{array}{c}(3) \\
\text { Crime }\end{array}$ & $\begin{array}{l}(4) \\
\text { Crime }\end{array}$ & $\begin{array}{c}(5) \\
\text { Vandalism }\end{array}$ & $\begin{array}{c}(6) \\
\text { Graffiti }\end{array}$ & $\begin{array}{c}(7) \\
\text { Litter }\end{array}$ \\
\hline Distance moved & $\begin{array}{c}0.00530 * * * \\
(0.00083)\end{array}$ & $\begin{array}{c}0.00449 * * * \\
(0.00084)\end{array}$ & $\begin{array}{c}0.00406 * * * \\
(0.00085)\end{array}$ & $\begin{array}{c}0.00343 * * * \\
(0.00102)\end{array}$ & $\begin{array}{c}0.00382 * * * \\
(0.00106)\end{array}$ & $\begin{array}{l}0.00251 * \\
(0.00135)\end{array}$ & $\begin{array}{r}0.00203 * * \\
(0.00100)\end{array}$ \\
\hline Personal/household characteristics & & Yes & Yes & Yes & Yes & Yes & Yes \\
\hline Tenure, housing characteristics & & & Yes & Yes & Yes & Yes & Yes \\
\hline Main reasons for moving & & & & Yes & Yes & Yes & Yes \\
\hline Government office regions & Yes & Yes & Yes & Yes & Yes & Yes & Yes \\
\hline Survey year dummies & Yes & Yes & Yes & Yes & Yes & Yes & Yes \\
\hline Pseudo R-squared & 0.0217 & 0.0302 & 0.0375 & 0.0392 & 0.0332 & 0.0440 & 0.0482 \\
\hline No. of obs. & 10543 & 10543 & 10543 & 10543 & 11594 & 10360 & 11689 \\
\hline
\end{tabular}

Notes: $* * *, * * *$ significance level at 1,5 , and $10 \%$ respectively. Age, sex and economic status are of household heads. The full regression results are reported in the unpublished Web-Appendix Table A1 
Table 3

Logit regressions for homeownership decision

(Dependent variable: Homeownership status)

\begin{tabular}{|c|c|c|c|c|}
\hline & $\begin{array}{c}\text { (1) } \\
\text { Distance moved } \\
\text { only }\end{array}$ & $\begin{array}{c}\text { (2) } \\
\text { Personal/HH } \\
\text { char. } \\
\end{array}$ & $\begin{array}{l}\text { (3) } \\
\text { Housing } \\
\text { char. }\end{array}$ & $\begin{array}{l}\text { (4) } \\
\text { Main reasons } \\
\text { for moving } \\
\end{array}$ \\
\hline Distance moved & $\begin{array}{c}-0.00527 * * * \\
(0.00069)\end{array}$ & $\begin{array}{c}-0.0108 * * * \\
(0.00084)\end{array}$ & $\begin{array}{c}-0.0140 * * * \\
(0.00095)\end{array}$ & $\begin{array}{c}-0.00538 * * * \\
(0.00118)\end{array}$ \\
\hline $\begin{array}{l}\text { Personal/household } \\
\text { characteristics }\end{array}$ & & Yes & Yes & Yes \\
\hline Tenure, housing characteristics & & & Yes & Yes \\
\hline Main reasons for moving & & & & Yes \\
\hline Government office regions & Yes & Yes & Yes & Yes \\
\hline Survey year dummies & Yes & Yes & Yes & Yes \\
\hline Pseudo R-squared & 0.0134 & 0.2131 & 0.3581 & 0.3771 \\
\hline No. of obs. & 13185 & 13185 & 13185 & 13185 \\
\hline
\end{tabular}

Notes: $* * *, * * *$ significance level at 1, 5, and 10\% respectively. Age, sex and economic status are of household heads. The full regression results are reported in the unpublished Web-Appendix Table A2. 


\section{Table 4}

\section{Logit regressions for tenure decision with interaction terms}

(Dependent variable: Homeownership status)

\begin{tabular}{|c|c|c|c|}
\hline & $\begin{array}{c}\text { (1) } \\
\text { Distance } \times \\
\text { Previous tenure }\end{array}$ & $\begin{array}{c}(2) \\
\text { Distance } \times \\
\text { HH income }\end{array}$ & $\begin{array}{c}(3) \\
\text { Distance } \times \\
\text { Reasons for } \\
\text { moving } \\
\end{array}$ \\
\hline \multicolumn{4}{|l|}{$\begin{array}{l}\text { Interaction term: } \\
\text { Distance moved } \times \text { Previous tenure }\end{array}$} \\
\hline Distance $\times$ prev. $\mathrm{HO}$ & $\begin{array}{c}-0.00957 * * * \\
(0.00141)\end{array}$ & & \\
\hline Distance $\times$ prev. public renter & $\begin{array}{l}-0.00377 \\
(0.00341)\end{array}$ & & \\
\hline Distance $\times$ prev. private renter & $\begin{array}{c}0.00014 \\
(0.00164)\end{array}$ & & \\
\hline \multicolumn{4}{|l|}{$\begin{array}{l}\text { Interaction term: } \\
\text { Distance moved } \times \text { HH income }\end{array}$} \\
\hline Distance $\times £ 0-9,999$ & & $\begin{array}{c}0.00045 \\
(0.00201)\end{array}$ & \\
\hline Distance $\times £ 10,000-19,999$ & & $\begin{array}{l}-0.00289 \\
(0.00191)\end{array}$ & \\
\hline Distance $\times £ 20,000-49,999$ & & $\begin{array}{c}-0.00996 * * * \\
(0.00168)\end{array}$ & \\
\hline Distance $\times £ 50,000$ or more & & $\begin{array}{c}-0.0129 * * * \\
(0.00328)\end{array}$ & \\
\hline \multicolumn{4}{|l|}{$\begin{array}{l}\text { Interaction term: } \\
\text { Distance moved } \times \text { Reasons for moving }\end{array}$} \\
\hline Distance $\times$ neighborhood & & & $\begin{array}{c}0.00123 \\
(0.00306)\end{array}$ \\
\hline Distance $\times$ housing & & & $\begin{array}{c}0.00192 \\
(0.00371)\end{array}$ \\
\hline Distance $\times$ had to move & & & $\begin{array}{c}-0.01080 * * * \\
(0.00386)\end{array}$ \\
\hline Distance $\times$ personal/family reasons & & & $\begin{array}{c}-0.00368^{* *} \\
(0.00187)\end{array}$ \\
\hline Distance $\times$ job-related reasons & & & $\begin{array}{c}-0.01147 * * * \\
(0.00223)\end{array}$ \\
\hline Personal/household characteristics & Yes & Yes & Yes \\
\hline Tenure, housing characteristics & Yes & Yes & Yes \\
\hline Main reasons for moving & Yes & Yes & Yes \\
\hline Government office regions & Yes & Yes & Yes \\
\hline Survey year dummies & Yes & Yes & Yes \\
\hline $\begin{array}{l}\text { Pseudo R-squared } \\
\text { No. of obs. }\end{array}$ & $\begin{array}{l}0.3785 \\
13185\end{array}$ & $\begin{array}{l}0.3785 \\
13185\end{array}$ & $\begin{array}{l}0.3782 \\
13185\end{array}$ \\
\hline
\end{tabular}

Notes: $* * *, * * *$ significance level at 1, 5, and 10\% respectively. Age, sex and economic status are of household heads. The full regression results are reported in the unpublished Web-Appendix Table A3. 
Table 5

Predicted probability of homeownership by distance moved (\%)

\begin{tabular}{|c|c|c|c|}
\hline & Specification & Marginal effect & Change in $\%$ points ${ }^{1}$ ) \\
\hline Total sample & Table 3 (4) & $-0.00538 * * *$ & $-3.23 \% * * *$ \\
\hline \multicolumn{4}{|l|}{ Panel A: By previous tenure } \\
\hline Previous homeowner & Table 4 (1) & $-0.00957 * * *$ & $-6.07 \% * * *$ \\
\hline Previous public renter & Table 4 (1) & -0.00377 & $-2.10 \%$ \\
\hline Previous private renter & Table $4(1)$ & 0.00014 & $+0.08 \%$ \\
\hline \multicolumn{4}{|c|}{ Panel B: By household income } \\
\hline$£ 0-£ 9,999$ & Table 4 (2) & 0.00045 & $+0.25 \%$ \\
\hline$£ 10,000-£ 19,999$ & Table 4 (2) & -0.00289 & $-1.71 \%$ \\
\hline$£ 20,000-£ 49,999$ & Table $4(2)$ & $-0.00996^{* * *}$ & $-6.10 \% * * *$ \\
\hline$£ 50,000$ or more & Table $4(2)$ & $-0.0129 * * *$ & $-8.58 \% * * *$ \\
\hline \multicolumn{4}{|l|}{ Panel C: By reason for moving } \\
\hline Neighborhood-related & Table 4 (3) & 0.00123 & $+0.65 \%$ \\
\hline Housing-related & Table 4 (3) & 0.00192 & $+0.54 \%$ \\
\hline Had to leave & Table 4 (3) & $-0.01080 * * *$ & $-3.79 \% * * *$ \\
\hline Personal/family-related & Table 4 (3) & $-0.00368 * *$ & $-2.18 \% * *$ \\
\hline Job-related & Table 4 (3) & $-0.01147 * * *$ & $-8.43 \% * * *$ \\
\hline
\end{tabular}

Note: ${ }^{1)}$ Change in the probability of homeownership for an increase in the distance moved by 1 standard deviation, measured at the means of the independent variables. 
Table 6

OLS regressions for length of stay

(Dependent variable: Length of stay)

\begin{tabular}{|c|c|c|c|c|}
\hline & $\begin{array}{c}(1) \\
\text { Distance } \\
\text { moved and } \\
\text { FEs only } \\
\end{array}$ & $\begin{array}{c}(2) \\
\text { Add } \\
\text { personal/HH } \\
\text { characteristics }\end{array}$ & $\begin{array}{c}\text { (3) } \\
\text { Add housing } \\
\text { characteristics }\end{array}$ & $\begin{array}{c}(4) \\
\text { Distance } \times \\
\text { Tenure }\end{array}$ \\
\hline Distance moved & $\begin{array}{c}-0.00093 * * * \\
(0.00017)\end{array}$ & $\begin{array}{c}-0.00129 * * * \\
(0.00017)\end{array}$ & $\begin{array}{c}-0.00114 * * * \\
(0.00020)\end{array}$ & \\
\hline \multicolumn{5}{|l|}{ Interaction terms: } \\
\hline Distance $\times$ Homeowner & & & & $\begin{array}{c}-0.00086 * * * \\
(0.00024)\end{array}$ \\
\hline Distance $\times$ Private renter & & & & $\begin{array}{c}-0.00172 * * * \\
(0.00029)\end{array}$ \\
\hline Personal/household characteristics & & Yes & Yes & Yes \\
\hline Tenure, housing characteristics & & & Yes & Yes \\
\hline Main reasons for moving & & & Yes & Yes \\
\hline Government office regions & Yes & Yes & Yes & Yes \\
\hline Survey year dummies & Yes & Yes & Yes & Yes \\
\hline Adj. R-squared & 0.0041 & 0.0383 & 0.0675 & 0.0677 \\
\hline No. of obs. & 37755 & 37755 & 37755 & 37755 \\
\hline
\end{tabular}

Notes: ***,*** significance level at 1, 5, and 10\% respectively. Age, sex and economic status are of household heads. The full regression results are reported in the unpublished Web-Appendix Table A4. 


\section{UNPUBLISHED WEB-APPENDIX}

Table A1

Ordered logit regression on neighborhood problem awareness

(Dependent variable: Seriousness of crime, vandalism, graffiti, litter in the area)

\begin{tabular}{|c|c|c|c|c|c|c|c|}
\hline & $\begin{array}{l}(1) \\
\text { Crime }\end{array}$ & $\begin{array}{c}(2) \\
\text { Crime }\end{array}$ & $\begin{array}{l}(3) \\
\text { Crime }\end{array}$ & $\begin{array}{l}(4) \\
\text { Crime }\end{array}$ & $\begin{array}{c}(5) \\
\text { Vandalism }\end{array}$ & $\begin{array}{c}(6) \\
\text { Graffiti }\end{array}$ & $\begin{array}{l}(7) \\
\text { Litter }\end{array}$ \\
\hline Distance moved & $\begin{array}{l}0.00530 * * * \\
(0.00083)\end{array}$ & $\begin{array}{l}0.00449 * * * \\
(0.00084)\end{array}$ & $\begin{array}{l}0.00406 * * * \\
(0.00085)\end{array}$ & $\begin{array}{c}0.00343 * * * \\
(0.00102)\end{array}$ & $\begin{array}{l}0.00382 * * * \\
(0.00106)\end{array}$ & $\begin{array}{l}0.00251^{*} \\
(0.00135)\end{array}$ & $\begin{array}{l}0.00203 * * \\
(0.00100)\end{array}$ \\
\hline Age & & $\begin{array}{c}0.003 \\
(0.011)\end{array}$ & $\begin{array}{l}-0.007 \\
(0.011)\end{array}$ & $\begin{array}{l}-0.011 \\
(0.011)\end{array}$ & $\begin{array}{c}0.003 \\
(0.011)\end{array}$ & $\begin{array}{l}-0.007 \\
(0.014)\end{array}$ & $\begin{array}{c}-0.025^{* *} \\
(0.011)\end{array}$ \\
\hline Age squared & & $\begin{array}{c}0.000127 \\
(0.000133)\end{array}$ & $\begin{array}{c}0.000199 \\
(0.000135)\end{array}$ & $\begin{array}{l}0.000241 * \\
(0.000136)\end{array}$ & $\begin{array}{l}-0.000053 \\
(0.000133)\end{array}$ & $\begin{array}{c}0.000186 \\
(0.000167)\end{array}$ & $\begin{array}{r}0.000318 * * \\
(0.000128)\end{array}$ \\
\hline Sex (Female excl.) & & $\begin{array}{c}0.054 \\
(0.053)\end{array}$ & $\begin{array}{c}0.052 \\
(0.054)\end{array}$ & $\begin{array}{c}0.051 \\
(0.054)\end{array}$ & $\begin{array}{c}0.054 \\
(0.054)\end{array}$ & $\begin{array}{c}0.077 \\
(0.066)\end{array}$ & $\begin{array}{l}-0.054 \\
(0.052)\end{array}$ \\
\hline $\begin{array}{l}\text { Economic status of } \mathrm{HH} \\
\text { (Full-time employed }\end{array}$ & & & & & & & \\
\hline Part-time employed & & $\begin{array}{l}-0.116 \\
(0.088)\end{array}$ & $\begin{array}{l}-0.137 \\
(0.089)\end{array}$ & $\begin{array}{l}-0.138 \\
(0.090)\end{array}$ & $\begin{array}{c}-0.172 * * \\
(0.087)\end{array}$ & $\begin{array}{l}-0.174 \\
(0.107)\end{array}$ & $\begin{array}{l}-0.246^{* * *} \\
(0.087)\end{array}$ \\
\hline Unemployed & & $\begin{array}{c}-0.319 * * \\
(0.127)\end{array}$ & $\begin{array}{c}-0.288 * * \\
(0.127)\end{array}$ & $\begin{array}{c}-0.285 * * \\
(0.127)\end{array}$ & $\begin{array}{l}-0.041 \\
(0.122)\end{array}$ & $\begin{array}{l}-0.148 \\
(0.149)\end{array}$ & $\begin{array}{l}-0.169 \\
(0.122)\end{array}$ \\
\hline Retired & & $\begin{array}{c}0.070 \\
(0.156)\end{array}$ & $\begin{array}{l}-0.002 \\
(0.157)\end{array}$ & $\begin{array}{l}-0.012 \\
(0.158)\end{array}$ & $\begin{array}{l}0.268^{*} \\
(0.160)\end{array}$ & $\begin{array}{l}-0.084 \\
(0.218)\end{array}$ & $\begin{array}{c}-0.316^{* *} \\
(0.155)\end{array}$ \\
\hline Inactive & & $\begin{array}{c}-0.315 * * * \\
(0.099)\end{array}$ & $\begin{array}{c}-0.288 * * * \\
(0.099)\end{array}$ & $\begin{array}{c}-0.291 * * * \\
(0.100)\end{array}$ & $\begin{array}{c}-0.239 * * \\
(0.097)\end{array}$ & $\begin{array}{l}-0.059 \\
(0.123)\end{array}$ & $\begin{array}{c}-0.258 * * * \\
(0.099)\end{array}$ \\
\hline $\begin{array}{l}\text { Household composition } \\
\text { (Single excl.) }\end{array}$ & & & & & & & \\
\hline Couple & & $\begin{array}{c}0.285 * * * \\
(0.076)\end{array}$ & $\begin{array}{c}0.210 * * * \\
(0.078)\end{array}$ & $\begin{array}{c}0.190 * * \\
(0.078)\end{array}$ & $\begin{array}{l}-0.005 \\
(0.080)\end{array}$ & $\begin{array}{c}0.031 \\
(0.099)\end{array}$ & $\begin{array}{c}0.005 \\
(0.078)\end{array}$ \\
\hline Lone parent & & $\begin{array}{c}0.107 \\
(0.095)\end{array}$ & $\begin{array}{c}0.023 \\
(0.096)\end{array}$ & $\begin{array}{c}0.032 \\
(0.097)\end{array}$ & $\begin{array}{c}0.088 \\
(0.097)\end{array}$ & $\begin{array}{c}0.134 \\
(0.123)\end{array}$ & $\begin{array}{c}0.015 \\
(0.097)\end{array}$ \\
\hline Multi-family HH & & $\begin{array}{c}0.348 * * * \\
(0.125)\end{array}$ & $\begin{array}{c}0.271 * * \\
(0.126)\end{array}$ & $\begin{array}{c}0.242 * \\
(0.126)\end{array}$ & $\begin{array}{l}-0.060 \\
(0.127)\end{array}$ & $\begin{array}{c}0.034 \\
(0.155)\end{array}$ & $\begin{array}{l}-0.130 \\
(0.125)\end{array}$ \\
\hline Number of children & & $\begin{array}{l}-0.028 \\
(0.025)\end{array}$ & $\begin{array}{c}-0.051^{*} \\
(0.027)\end{array}$ & $\begin{array}{c}-0.057 * * \\
(0.027)\end{array}$ & $\begin{array}{c}-0.064 * * \\
(0.028)\end{array}$ & $\begin{array}{l}-0.048 \\
(0.034)\end{array}$ & $\begin{array}{l}-0.025 \\
(0.027)\end{array}$ \\
\hline Number of adults & & $\begin{array}{c}-0.173 * * * \\
(0.045) \\
\end{array}$ & $\begin{array}{c}-0.188 * * * \\
(0.047)\end{array}$ & $\begin{array}{c}-0.189 * * * \\
(0.047)\end{array}$ & $\begin{array}{c}-0.070 \\
(0.048) \\
\end{array}$ & $\begin{array}{c}-0.012 \\
(0.060) \\
\end{array}$ & $\begin{array}{c}-0.073 \\
(0.047) \\
\end{array}$ \\
\hline
\end{tabular}


Table A1-Continued

\begin{tabular}{|c|c|c|c|c|c|c|c|}
\hline & $\begin{array}{c}(1) \\
\text { Crime }\end{array}$ & $\begin{array}{l}(2) \\
\text { Crime } \\
\end{array}$ & $\begin{array}{l}(3) \\
\text { Crime } \\
\end{array}$ & $\begin{array}{l}(4) \\
\text { Crime } \\
\end{array}$ & $\begin{array}{c}(5) \\
\text { Vandalism }\end{array}$ & $\begin{array}{c}(6) \\
\text { Graffiti } \\
\end{array}$ & $\begin{array}{l}(7) \\
\text { Litter }\end{array}$ \\
\hline \multicolumn{8}{|l|}{$\begin{array}{l}\text { Household real income } \\
\text { (£0-£9,999 excl.) }\end{array}$} \\
\hline$£ 10,000-£ 19,999$ & & $\begin{array}{c}0.078 \\
(0.068)\end{array}$ & $\begin{array}{c}0.013 \\
(0.069)\end{array}$ & $\begin{array}{c}0.017 \\
(0.069)\end{array}$ & $\begin{array}{c}0.053 \\
(0.068)\end{array}$ & $\begin{array}{c}0.189 * * \\
(0.085)\end{array}$ & $\begin{array}{l}-0.062 \\
(0.067)\end{array}$ \\
\hline$£ 20,000-£ 49,999$ & & $\begin{array}{c}0.230 * * * \\
(0.073)\end{array}$ & $\begin{array}{c}0.092 \\
(0.076)\end{array}$ & $\begin{array}{c}0.094 \\
(0.076)\end{array}$ & $\begin{array}{c}0.192 * * \\
(0.076)\end{array}$ & $\begin{array}{c}0.185^{* *} \\
(0.094)\end{array}$ & $\begin{array}{l}-0.026 \\
(0.075)\end{array}$ \\
\hline$£ 50,000$ or more & & $\begin{array}{c}0.149 \\
(0.098)\end{array}$ & $\begin{array}{c}0.005 \\
(0.108)\end{array}$ & $\begin{array}{c}0.011 \\
(0.108)\end{array}$ & $\begin{array}{c}0.293 * * \\
(0.116)\end{array}$ & $\begin{array}{c}0.070 \\
(0.135)\end{array}$ & $\begin{array}{c}0.038 \\
(0.114)\end{array}$ \\
\hline \multicolumn{3}{|l|}{ Homeowner (Private renter excl.) } & $\begin{array}{c}-0.110 * * \\
(0.050)\end{array}$ & $\begin{array}{c}-0.109 * * \\
(0.051)\end{array}$ & $\begin{array}{l}-0.039 \\
(0.051)\end{array}$ & $\begin{array}{c}-0.190 * * * \\
(0.065)\end{array}$ & $\begin{array}{l}-0.057 \\
(0.050)\end{array}$ \\
\hline \multicolumn{3}{|l|}{ Number of bedrooms } & $\begin{array}{l}-0.052^{*} \\
(0.031)\end{array}$ & $\begin{array}{l}-0.052 * \\
(0.031)\end{array}$ & $\begin{array}{l}-0.039 \\
(0.032)\end{array}$ & $\begin{array}{c}-0.124 * * * \\
(0.041)\end{array}$ & $\begin{array}{c}-0.114 * * * \\
(0.032)\end{array}$ \\
\hline \multicolumn{8}{|l|}{$\begin{array}{l}\text { Accommodation type } \\
\text { (Detached/bungalow excl.) }\end{array}$} \\
\hline Semi-detached & & & $\begin{array}{l}-0.066 \\
(0.067)\end{array}$ & $\begin{array}{l}-0.069 \\
(0.067)\end{array}$ & $\begin{array}{c}-0.171 * * \\
(0.074)\end{array}$ & $\begin{array}{l}-0.088 \\
(0.098)\end{array}$ & $\begin{array}{l}-0.111 \\
(0.075)\end{array}$ \\
\hline Terraced & & & $\begin{array}{l}-0.313 * * * \\
(0.072)\end{array}$ & $\begin{array}{c}-0.297 * * * \\
(0.072)\end{array}$ & $\begin{array}{c}-0.458 * * * \\
(0.077)\end{array}$ & $\begin{array}{c}-0.404 * * * \\
(0.101)\end{array}$ & $\begin{array}{c}-0.650 * * * \\
(0.077)\end{array}$ \\
\hline Purpose-built flat & & & $\begin{array}{c}-0.281 * * * \\
(0.096)\end{array}$ & $\begin{array}{c}-0.260 * * * \\
(0.096)\end{array}$ & $\begin{array}{c}-0.418 * * * \\
(0.102)\end{array}$ & $\begin{array}{c}-0.398 * * * \\
(0.130)\end{array}$ & $\begin{array}{c}-0.433 * * * \\
(0.101)\end{array}$ \\
\hline Converted flat & & & $\begin{array}{c}-0.650 * * * \\
(0.102)\end{array}$ & $\begin{array}{l}-0.639 * * * \\
(0.103)\end{array}$ & $\begin{array}{c}-0.671 * * * \\
(0.107)\end{array}$ & $\begin{array}{c}-0.630 * * * \\
(0.133)\end{array}$ & $\begin{array}{c}-0.846 * * * \\
(0.105)\end{array}$ \\
\hline \multicolumn{8}{|l|}{$\begin{array}{l}\text { House values - council tax band } \\
\text { (Up to } £ 40 \mathrm{k} \text { excl.) }\end{array}$} \\
\hline Up to $£ 52 k$ & & & $\begin{array}{c}0.295 * * * \\
(0.066)\end{array}$ & $\begin{array}{c}0.295 * * * \\
(0.066)\end{array}$ & $\begin{array}{c}0.326 * * * \\
(0.065)\end{array}$ & $\begin{array}{c}0.335^{* * *} \\
(0.080)\end{array}$ & $\begin{array}{c}0.401 * * * \\
(0.063)\end{array}$ \\
\hline Up to $£ 68 \mathrm{k}$ & & & $\begin{array}{c}0.392 * * * \\
(0.069)\end{array}$ & $\begin{array}{c}0.387 * * * \\
(0.069)\end{array}$ & $\begin{array}{c}0.523 * * * \\
(0.071)\end{array}$ & $\begin{array}{c}0.503 * * * \\
(0.088)\end{array}$ & $\begin{array}{c}0.610 * * * \\
(0.070)\end{array}$ \\
\hline Up to $£ 88 \mathrm{k}$ & & & $\begin{array}{c}0.392 * * * \\
(0.081)\end{array}$ & $\begin{array}{l}0.393 * * * \\
(0.081)\end{array}$ & $\begin{array}{c}0.496 * * * \\
(0.082)\end{array}$ & $\begin{array}{l}0.524 * * * \\
(0.104)\end{array}$ & $\begin{array}{c}0.679 * * * \\
(0.081)\end{array}$ \\
\hline Up to $£ 120 \mathrm{k}$ & & & $\begin{array}{c}0.352 * * * \\
(0.095)\end{array}$ & $\begin{array}{c}0.346 * * * \\
(0.096)\end{array}$ & $\begin{array}{c}0.630 * * * \\
(0.101)\end{array}$ & $\begin{array}{l}0.691 * * * \\
(0.128)\end{array}$ & $\begin{array}{c}0.791 * * * \\
(0.102)\end{array}$ \\
\hline Up to $£ 160 \mathrm{k}$ & & & $\begin{array}{c}0.419 * * * \\
(0.121)\end{array}$ & $\begin{array}{c}0.409 * * * \\
(0.122)\end{array}$ & $\begin{array}{c}0.597 * * * \\
(0.129)\end{array}$ & $\begin{array}{c}0.731 * * * \\
(0.164)\end{array}$ & $\begin{array}{c}1.099 * * * \\
(0.136)\end{array}$ \\
\hline Up to $£ 320 \mathrm{k}$ & & & $\begin{array}{c}0.450 * * * \\
(0.138)\end{array}$ & $\begin{array}{c}0.437 * * * \\
(0.138)\end{array}$ & $\begin{array}{l}0.741 * * * \\
(0.152)\end{array}$ & $\begin{array}{c}0.966 * * * \\
(0.187)\end{array}$ & $\begin{array}{c}1.310 * * * \\
(0.159)\end{array}$ \\
\hline Over $£ 320 \mathrm{k}$ & & & $\begin{array}{l}-0.059 \\
(0.225)\end{array}$ & $\begin{array}{l}-0.061 \\
(0.225)\end{array}$ & $\begin{array}{l}0.912 * * * \\
(0.295)\end{array}$ & $\begin{array}{l}1.668 * * * \\
(0.426)\end{array}$ & $\begin{array}{c}0.855^{* * * *} \\
(0.286)\end{array}$ \\
\hline
\end{tabular}


Table A1-Continued

\begin{tabular}{|c|c|c|c|c|c|c|c|}
\hline & $\begin{array}{c}(1) \\
\text { Crime }\end{array}$ & $\begin{array}{c}(2) \\
\text { Crime }\end{array}$ & $\begin{array}{c}(3) \\
\text { Crime }\end{array}$ & $\begin{array}{c}(4) \\
\text { Crime }\end{array}$ & $\begin{array}{c}(5) \\
\text { Vandalism }\end{array}$ & $\begin{array}{c}(6) \\
\text { Graffiti }\end{array}$ & $\begin{array}{c}(7) \\
\text { Litter }\end{array}$ \\
\hline \multicolumn{8}{|c|}{$\begin{array}{l}\text { Main reasons for moving } \\
\text { (Neighborhood-related excl.) }\end{array}$} \\
\hline Housing-related & & & & $\begin{array}{c}-0.325 * * * \\
(0.071)\end{array}$ & $\begin{array}{c}-0.267 * * * \\
(0.077)\end{array}$ & $\begin{array}{c}-0.338 * * * \\
(0.099)\end{array}$ & $\begin{array}{c}-0.357 * * * \\
(0.076)\end{array}$ \\
\hline Had to leave & & & & $\begin{array}{c}-0.357 * * * \\
(0.081)\end{array}$ & $\begin{array}{c}-0.309 * * * \\
(0.086)\end{array}$ & $\begin{array}{c}-0.341 * * * \\
(0.110)\end{array}$ & $\begin{array}{c}-0.398 * * * \\
(0.084)\end{array}$ \\
\hline Personal/family-related & & & & $\begin{array}{c}-0.382 * * * \\
(0.070)\end{array}$ & $\begin{array}{c}-0.330 * * * \\
(0.076)\end{array}$ & $\begin{array}{c}-0.355^{* * *} \\
(0.097)\end{array}$ & $\begin{array}{c}-0.358 * * * \\
(0.074)\end{array}$ \\
\hline Job-related & & & & $\begin{array}{c}-0.244 * * * \\
(0.092)\end{array}$ & $\begin{array}{c}-0.326 * * * \\
(0.098)\end{array}$ & $\begin{array}{c}-0.298 * * \\
(0.125)\end{array}$ & $\begin{array}{c}-0.350 * * * \\
(0.095)\end{array}$ \\
\hline Constant & $\begin{array}{c}0.714 * * * \\
(0.129)\end{array}$ & $\begin{array}{c}0.966 * * * \\
(0.258)\end{array}$ & $\begin{array}{c}0.315 \\
(0.282)\end{array}$ & $\begin{array}{l}-0.084 \\
(0.292)\end{array}$ & $\begin{array}{l}-0.935^{* * * *} \\
(0.290)\end{array}$ & $\begin{array}{c}-1.712 * * * \\
(0.360)\end{array}$ & $\begin{array}{c}-1.955^{* * *} \\
(0.283)\end{array}$ \\
\hline Government office regions & Yes & Yes & Yes & Yes & Yes & Yes & Yes \\
\hline Survey year dummies & Yes & Yes & Yes & Yes & Yes & Yes & Yes \\
\hline Pseudo R-squared & 0.0217 & 0.0302 & 0.0375 & 0.0392 & 0.0332 & 0.0440 & 0.0482 \\
\hline No. of obs. & 10543 & 10543 & 10543 & 10543 & 11594 & 10360 & 11689 \\
\hline
\end{tabular}

Notes: ***,**,* significance level at 1, 5, and 10\% respectively. Age, sex and economic status are of household heads. 
Table A2

Logit regressions for homeownership decision

(Dependent variable: Homeownership status)

\begin{tabular}{|c|c|c|c|c|}
\hline & $\begin{array}{c}(1) \\
\text { Distance moved } \\
\text { only } \\
\end{array}$ & $\begin{array}{c}(2) \\
\text { Personal/HH } \\
\text { char. }\end{array}$ & $\begin{array}{c}(3) \\
\text { Housing } \\
\text { char. }\end{array}$ & $\begin{array}{c}(4) \\
\text { Main reasons } \\
\text { for moving }\end{array}$ \\
\hline Distance moved & $\begin{array}{c}-0.00527^{* * * *} \\
(0.00069)\end{array}$ & $\begin{array}{c}-0.0108 * * * \\
(0.00084)\end{array}$ & $\begin{array}{c}-0.0140 * * * \\
(0.00095)\end{array}$ & $\begin{array}{c}-0.00538^{* * * *} \\
(0.00118)\end{array}$ \\
\hline Age & & $\begin{array}{c}0.124 * * * \\
(0.012)\end{array}$ & $\begin{array}{c}0.013 \\
(0.013)\end{array}$ & $\begin{array}{c}0.010 \\
(0.013)\end{array}$ \\
\hline Age squared & & $\begin{array}{c}-0.000827 * * * \\
(0.000141)\end{array}$ & $\begin{array}{c}0.000060 \\
(0.000151)\end{array}$ & $\begin{array}{c}0.000077 \\
(0.000154)\end{array}$ \\
\hline Sex (Female excl.) & & $\begin{array}{c}0.365 * * * \\
(0.060)\end{array}$ & $\begin{array}{c}0.331 * * * \\
(0.069)\end{array}$ & $\begin{array}{c}0.300 * * * \\
(0.069)\end{array}$ \\
\hline \multicolumn{5}{|c|}{$\begin{array}{l}\text { Economic status of } H H \\
\text { (Full-time employed excl.) }\end{array}$} \\
\hline Part-time employed & & $\begin{array}{c}-0.274 * * * \\
(0.091)\end{array}$ & $\begin{array}{c}-0.388 * * * \\
(0.101)\end{array}$ & $\begin{array}{c}-0.448 * * * \\
(0.102)\end{array}$ \\
\hline Unemployed & & $\begin{array}{c}-1.116^{* * * *} \\
(0.129)\end{array}$ & $\begin{array}{c}-0.851 * * * \\
(0.134)\end{array}$ & $\begin{array}{c}-1.033 * * * \\
(0.138)\end{array}$ \\
\hline Retired & & $\begin{array}{c}0.940 * * * \\
(0.177)\end{array}$ & $\begin{array}{c}0.709 * * * \\
(0.179)\end{array}$ & $\begin{array}{c}0.518^{* * *} \\
(0.184)\end{array}$ \\
\hline Inactive & & $\begin{array}{c}-1.195^{* * *} \\
(0.100)\end{array}$ & $\begin{array}{c}-1.046 * * * \\
(0.105)\end{array}$ & $\begin{array}{c}-1.135^{* * *} \\
(0.107)\end{array}$ \\
\hline \multicolumn{5}{|l|}{$\begin{array}{l}\text { Household composition } \\
\quad \text { (Single excl.) }\end{array}$} \\
\hline Couple & & $\begin{array}{l}0.832 * * * \\
(0.084)\end{array}$ & $\begin{array}{c}0.728 * * * \\
(0.095)\end{array}$ & $\begin{array}{c}0.687 * * * \\
(0.097)\end{array}$ \\
\hline Lone parent & & $\begin{array}{c}0.002 \\
(0.097)\end{array}$ & $\begin{array}{c}-0.392 * * * \\
(0.106)\end{array}$ & $\begin{array}{c}-0.369 * * * \\
(0.107)\end{array}$ \\
\hline Multi-family $\mathrm{HH}$ & & $\begin{array}{c}-0.536^{* * *} \\
(0.139)\end{array}$ & $\begin{array}{c}-0.685^{* * *} \\
(0.160)\end{array}$ & $\begin{array}{c}-0.712 * * * \\
(0.162)\end{array}$ \\
\hline Number of children & & $\begin{array}{c}0.156^{* * *} \\
(0.026)\end{array}$ & $\begin{array}{c}-0.148 * * * \\
(0.030)\end{array}$ & $\begin{array}{c}-0.147 * * * \\
(0.030)\end{array}$ \\
\hline Number of adults & & $\begin{array}{c}-0.139 * * * \\
(0.049)\end{array}$ & $\begin{array}{c}-0.355^{* * *} \\
(0.053)\end{array}$ & $\begin{array}{c}-0.365 * * * \\
(0.054)\end{array}$ \\
\hline \multicolumn{5}{|l|}{$\begin{array}{l}\text { Household real income } \\
\text { (£0-£9,999 excl.) }\end{array}$} \\
\hline$£ 10,000-£ 19,999$ & & $\begin{array}{l}0.861 * * * \\
(0.071)\end{array}$ & $\begin{array}{c}0.669 * * * \\
(0.079)\end{array}$ & $\begin{array}{c}0.703 * * * \\
(0.080)\end{array}$ \\
\hline$£ 20,000-£ 49,999$ & & $\begin{array}{c}1.468 * * * \\
(0.076)\end{array}$ & $\begin{array}{c}0.937 * * * \\
(0.088)\end{array}$ & $\begin{array}{c}0.987 * * * \\
(0.090)\end{array}$ \\
\hline$£ 50,000$ or more & & $\begin{array}{l}1.748 * * * \\
(0.109)\end{array}$ & $\begin{array}{c}0.832 * * * \\
(0.136)\end{array}$ & $\begin{array}{c}0.832 * * * \\
(0.137)\end{array}$ \\
\hline \multicolumn{5}{|l|}{$\begin{array}{l}\text { Previous tenure status } \\
\text { (Previous HO excl.) }\end{array}$} \\
\hline Previous public renter & & & $\begin{array}{c}-1.184 * * * \\
(0.092)\end{array}$ & $\begin{array}{c}-1.285^{* * *} \\
(0.093)\end{array}$ \\
\hline Previous private renter & & & $\begin{array}{c}-1.815 * * * \\
(0.054)\end{array}$ & $\begin{array}{c}-2.019 * * * \\
(0.061)\end{array}$ \\
\hline Number of bedrooms & & & $\begin{array}{c}0.374 * * * \\
(0.039)\end{array}$ & $\begin{array}{c}0.370 * * * \\
(0.039)\end{array}$ \\
\hline
\end{tabular}


Table A2-Continued

\begin{tabular}{|c|c|c|c|c|}
\hline & $\begin{array}{c}\text { (1) } \\
\text { Distance moved } \\
\text { only } \\
\end{array}$ & $\begin{array}{c}(2) \\
\text { Personal/HH } \\
\text { char. } \\
\end{array}$ & $\begin{array}{c}\text { (3) } \\
\text { Housing } \\
\text { char. } \\
\end{array}$ & $\begin{array}{c}(4) \\
\text { Main reasons } \\
\text { for moving } \\
\end{array}$ \\
\hline \multicolumn{5}{|l|}{$\begin{array}{l}\text { Accommodation type } \\
\text { (Detached/bungalow excl.) }\end{array}$} \\
\hline Semi-detached & & & $\begin{array}{c}0.010 \\
(0.082)\end{array}$ & $\begin{array}{l}-0.002 \\
(0.084)\end{array}$ \\
\hline Terraced & & & $\begin{array}{c}-0.190 * * \\
(0.087)\end{array}$ & $\begin{array}{c}-0.210 * * \\
(0.090)\end{array}$ \\
\hline Purpose-built flat & & & $\begin{array}{l}-0.940 * * * \\
(0.113)\end{array}$ & $\begin{array}{c}-0.912 * * * \\
(0.115)\end{array}$ \\
\hline Converted flat & & & $\begin{array}{c}-1.418 * * * \\
(0.120)\end{array}$ & $\begin{array}{l}-1.410 * * * \\
(0.123)\end{array}$ \\
\hline \multicolumn{5}{|c|}{$\begin{array}{l}\text { House value - council tax band } \\
\quad \text { (Up to } £ 40 \mathrm{k} \text { excl.) }\end{array}$} \\
\hline Up to $£ 52 \mathrm{k}$ & & & $\begin{array}{c}0.266 * * * \\
(0.078)\end{array}$ & $\begin{array}{c}0.254 * * * \\
(0.078)\end{array}$ \\
\hline Up to $£ 68 \mathrm{k}$ & & & $\begin{array}{c}0.467 * * * \\
(0.083)\end{array}$ & $\begin{array}{c}0.456^{* * *} * \\
(0.084)\end{array}$ \\
\hline Up to $£ 88 \mathrm{k}$ & & & $\begin{array}{c}0.572 * * * \\
(0.095)\end{array}$ & $\begin{array}{c}0.561 * * * \\
(0.097)\end{array}$ \\
\hline Up to $£ 120 \mathrm{k}$ & & & $\begin{array}{l}0.359 * * * \\
(0.115)\end{array}$ & $\begin{array}{l}0.422 * * * \\
(0.117)\end{array}$ \\
\hline Up to $£ 160 \mathrm{k}$ & & & $\begin{array}{c}0.603 * * * \\
(0.149)\end{array}$ & $\begin{array}{c}0.617 * * * \\
(0.152)\end{array}$ \\
\hline Up to $£ 320 \mathrm{k}$ & & & $\begin{array}{c}0.329^{*} \\
(0.178)\end{array}$ & $\begin{array}{c}0.382 * * \\
(0.184)\end{array}$ \\
\hline Over $320 \mathrm{k}$ & & & $\begin{array}{c}0.171 \\
(0.356)\end{array}$ & $\begin{array}{c}0.302 \\
(0.357)\end{array}$ \\
\hline \multicolumn{5}{|c|}{$\begin{array}{l}\text { Main reasons for moving } \\
\quad \text { (Neighborhood-related excl.) }\end{array}$} \\
\hline Housing-related & & & & $\begin{array}{l}-0.094 \\
(0.077)\end{array}$ \\
\hline Had to leave & & & & $\begin{array}{c}0.632 * * * \\
(0.095)\end{array}$ \\
\hline Personal/family-related & & & & $\begin{array}{c}-0.300 * * * \\
(0.081)\end{array}$ \\
\hline Job-related & & & & $\begin{array}{c}-1.130 * * * \\
(0.105)\end{array}$ \\
\hline Constant & $\begin{array}{l}0.881 * * * \\
(0.127)\end{array}$ & $\begin{array}{l}-3.646 * * * \\
(0.294)\end{array}$ & $\begin{array}{l}-0.040 \\
(0.356)\end{array}$ & $\begin{array}{c}0.330 \\
(0.368)\end{array}$ \\
\hline Government office regions & Yes & Yes & Yes & Yes \\
\hline Survey year dummies & Yes & Yes & Yes & Yes \\
\hline Pseudo R-squared & 0.0134 & 0.2131 & 0.3581 & 0.3771 \\
\hline No. of obs. & 13185 & 13185 & 13185 & 13185 \\
\hline
\end{tabular}

Notes: $* * *, * * *$ significance level at 1,5 , and $10 \%$ respectively. Age, sex and economic status are of household heads. 
Table A3

Logit regressions for tenure decision with interaction terms

(Dependent variable: Homeownership status)

\begin{tabular}{|c|c|c|c|}
\hline & $\begin{array}{c}(1) \\
\text { Distance } \times \text { Previous } \\
\text { tenure }\end{array}$ & $\begin{array}{c}(2) \\
\text { Distance } \times \mathrm{HH} \\
\text { income }\end{array}$ & $\begin{array}{c}(3) \\
\text { Distance } \times \text { Reasons } \\
\text { for moving }\end{array}$ \\
\hline \multicolumn{4}{|l|}{ Interaction term: } \\
\hline \multicolumn{4}{|l|}{ Distance moved $\times$ Previous tenure } \\
\hline Distance $\times$ prev. $\mathrm{HO}$ & $\begin{array}{c}-0.00957 * * * \\
(0.00141)\end{array}$ & & \\
\hline Distance $\times$ prev. public renter & $\begin{array}{l}-0.00377 \\
(0.00341)\end{array}$ & & \\
\hline Distance $\times$ prev. private renter & $\begin{array}{c}0.00014 \\
(0.00164)\end{array}$ & & \\
\hline \multicolumn{4}{|l|}{ Interaction term: } \\
\hline \multicolumn{4}{|l|}{ Distance moved $\times H H$ income } \\
\hline Distance $\times £ 0-9,999$ & & $\begin{array}{c}0.00045 \\
(0.00201)\end{array}$ & \\
\hline Distance $\times £ 10,000-19,999$ & & $\begin{array}{l}-0.00289 \\
(0.00191)\end{array}$ & \\
\hline Distance $\times £ 20,000-49,999$ & & $\begin{array}{c}-0.00996 * * * \\
(0.00168)\end{array}$ & \\
\hline Distance $\times £ 50,000$ or more & & $\begin{array}{l}-0.0129 * * * \\
(0.00328)\end{array}$ & \\
\hline \multicolumn{4}{|l|}{ Interaction term: } \\
\hline $\begin{array}{l}\text { Distance moved } \times \text { Reasons for moving } \\
\text { Distance } \times \text { neighborhood }\end{array}$ & & & $\begin{array}{c}0.00123 \\
(0.00306)\end{array}$ \\
\hline Distance $\times$ housing & & & $\begin{array}{c}0.00192 \\
(0.00371)\end{array}$ \\
\hline Distance $\times$ had to move & & & $\begin{array}{c}-0.01080 * * * \\
(0.00386)\end{array}$ \\
\hline Distance $\times$ personal/family reasons & & & $\begin{array}{c}-0.00368 * * \\
(0.00187)\end{array}$ \\
\hline Distance $\times$ job-related reasons & & & $\begin{array}{c}-0.01147 * * * \\
(0.00223)\end{array}$ \\
\hline Age & $\begin{array}{c}0.009 \\
(0.013)\end{array}$ & $\begin{array}{c}0.010 \\
(0.013)\end{array}$ & $\begin{array}{c}0.008 \\
(0.013)\end{array}$ \\
\hline Age squared & $\begin{array}{c}0.000089 \\
(0.000153)\end{array}$ & $\begin{array}{c}0.000074 \\
(0.000154)\end{array}$ & $\begin{array}{c}0.000094 \\
(0.000155)\end{array}$ \\
\hline Sex (Female excl.) & $\begin{array}{c}0.295 * * * \\
(0.069)\end{array}$ & $\begin{array}{l}0.297 * * * \\
(0.069)\end{array}$ & $\begin{array}{c}0.295 * * * \\
(0.069)\end{array}$ \\
\hline \multicolumn{4}{|l|}{$\begin{array}{l}\text { Economic status of } H H \\
\text { (Full-time employed excl.) }\end{array}$} \\
\hline Part-time employed & $\begin{array}{l}-0.440 * * * \\
(0.103)\end{array}$ & $\begin{array}{c}-0.440 * * * \\
(0.103)\end{array}$ & $\begin{array}{l}-0.455^{* * *} \\
(0.102)\end{array}$ \\
\hline Unemployed & $\begin{array}{c}-1.018 * * * \\
(0.139)\end{array}$ & $\begin{array}{c}-1.044 * * * \\
(0.139)\end{array}$ & $\begin{array}{c}-1.052 * * * \\
(0.138)\end{array}$ \\
\hline Retired & $\begin{array}{c}0.544 * * * \\
(0.184)\end{array}$ & $\begin{array}{c}0.489 * * * \\
(0.183)\end{array}$ & $\begin{array}{c}0.477 * * \\
(0.185)\end{array}$ \\
\hline Inactive & $\begin{array}{c}-1.117 * * * \\
(0.107)\end{array}$ & $\begin{array}{c}-1.144 * * * \\
(0.107)\end{array}$ & $\begin{array}{c}-1.145^{* * * *} \\
(0.107)\end{array}$ \\
\hline \multicolumn{4}{|l|}{ Household composition (Single excl.) } \\
\hline Couple & $\begin{array}{c}0.697 * * * \\
(0.097)\end{array}$ & $\begin{array}{c}0.676 * * * \\
(0.097)\end{array}$ & $\begin{array}{c}0.671 * * * \\
(0.097)\end{array}$ \\
\hline Lone parent & $\begin{array}{c}-0.378 * * * \\
(0.108)\end{array}$ & $\begin{array}{c}-0.348 * * * \\
(0.107)\end{array}$ & $\begin{array}{c}-0.370 * * * \\
(0.107)\end{array}$ \\
\hline Multi-family $\mathrm{HH}$ & $\begin{array}{c}-0.683 * * * \\
(0.162)\end{array}$ & $\begin{array}{c}-0.717 * * * \\
(0.162)\end{array}$ & $\begin{array}{c}-0.736 * * * \\
(0.162)\end{array}$ \\
\hline Number of children & $\begin{array}{c}-0.148 * * * \\
(0.030)\end{array}$ & $\begin{array}{c}-0.145^{* * * *} \\
(0.030)\end{array}$ & $\begin{array}{c}-0.143 * * * \\
(0.030)\end{array}$ \\
\hline Number of adults & $\begin{array}{c}-0.369 * * * \\
(0.054) \\
\end{array}$ & $\begin{array}{c}-0.359 * * * \\
(0.054) \\
\end{array}$ & $\begin{array}{c}-0.360 * * * \\
(0.054) \\
\end{array}$ \\
\hline
\end{tabular}


Table A3-Continued

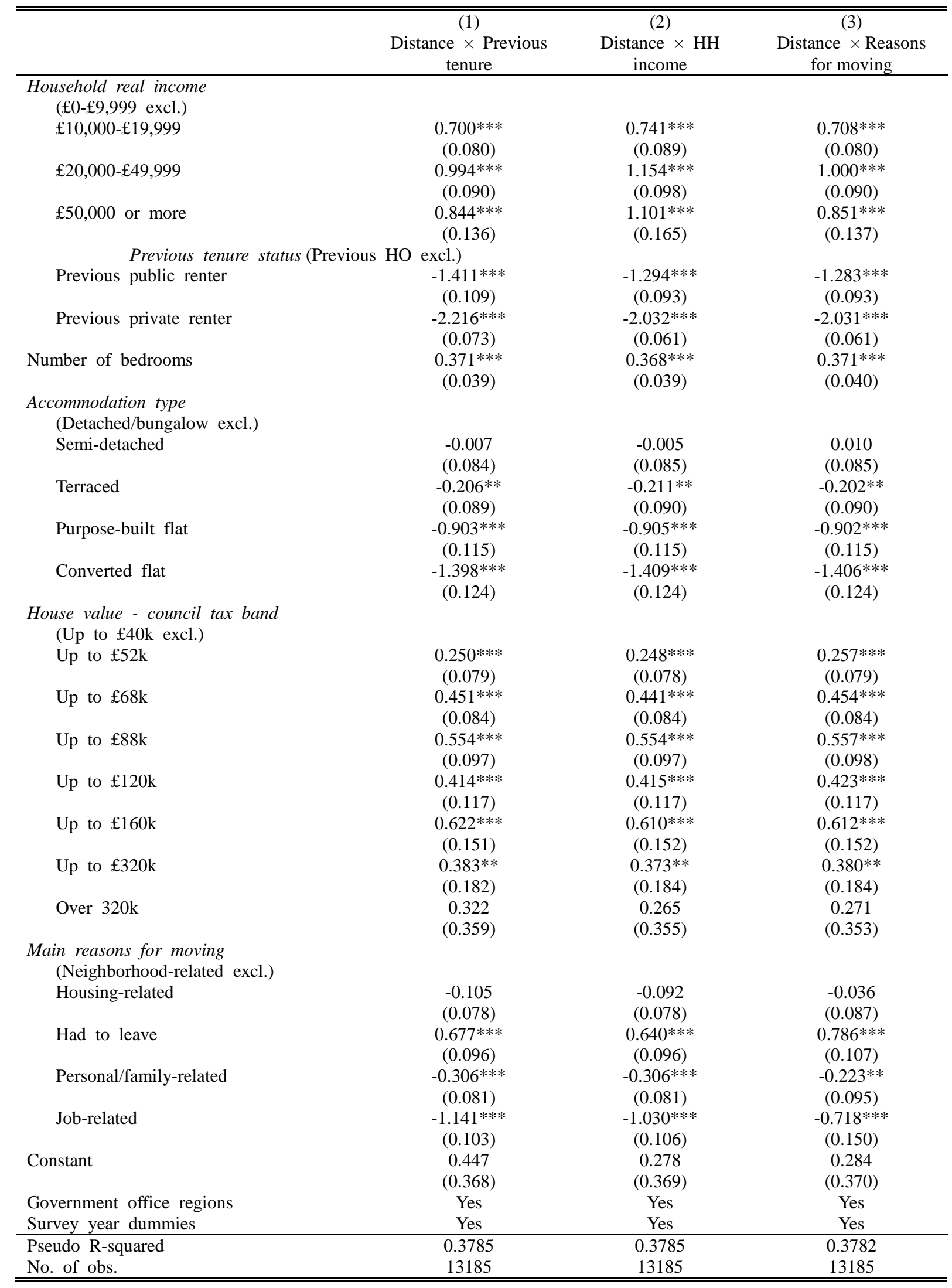

Notes: $* * *, * * *$ significance level at 1,5 , and $10 \%$ respectively. Age, sex and economic status are of household heads. 
Table A4

OLS regressions for Length of stay

(Dependent variable: Length of stay)

\begin{tabular}{|c|c|c|c|c|}
\hline & $\begin{array}{l}\text { (1) } \\
\begin{array}{l}\text { Distance moved } \\
\text { only }\end{array}\end{array}$ & $\begin{array}{c}(2) \\
\text { Personal/HH } \\
\text { characteristics }\end{array}$ & $\begin{array}{c}\text { (3) } \\
\text { Housing } \\
\text { characteristics }\end{array}$ & $\begin{array}{c}(4) \\
\text { Distance } \times \\
\text { Tenure }\end{array}$ \\
\hline Distance moved & $\begin{array}{c}-0.00093^{* * *} \\
(0.00017)\end{array}$ & $\begin{array}{c}-0.00129 * * * \\
(0.00017)\end{array}$ & $\begin{array}{c}-0.00114 * * * \\
(0.00020)\end{array}$ & \\
\hline \multicolumn{5}{|l|}{$\begin{array}{l}\text { Interaction terms: } \\
\text { Distance moved } \times \text { Tenure type }\end{array}$} \\
\hline $\begin{array}{l}\text { Distance } \times \text { Homeowner } \\
\text { Distance } \times \text { Private renter }\end{array}$ & & & & $\begin{array}{c}-0.00086 * * * \\
(0.00024) \\
-0.00172 * * * \\
(0.00029)\end{array}$ \\
\hline Age & & $\begin{array}{c}0.030 * * * \\
(0.002)\end{array}$ & $\begin{array}{c}0.023 * * * \\
(0.002)\end{array}$ & $\begin{array}{c}0.023 * * * \\
(0.002)\end{array}$ \\
\hline Age squared & & $\begin{array}{l}-0.000239 * * * \\
(0.000025)\end{array}$ & $\begin{array}{c}-0.000184 * * * \\
(0.000025)\end{array}$ & $\begin{array}{c}-0.000183 * * * \\
(0.000025)\end{array}$ \\
\hline Sex (Female excl.) & & $\begin{array}{c}0.014 \\
(0.012)\end{array}$ & $\begin{array}{l}-0.003 \\
(0.011)\end{array}$ & $\begin{array}{l}-0.003 \\
(0.011)\end{array}$ \\
\hline \multicolumn{5}{|l|}{$\begin{array}{l}\text { Economic status of } \mathrm{HH} \\
\text { (Full-time employed excl.) }\end{array}$} \\
\hline Part-time employed & & $\begin{array}{l}-0.030 \\
(0.019)\end{array}$ & $\begin{array}{l}-0.008 \\
(0.018)\end{array}$ & $\begin{array}{l}-0.009 \\
(0.018)\end{array}$ \\
\hline Unemployed & & $\begin{array}{c}-0.067 * * \\
(0.026)\end{array}$ & $\begin{array}{l}0.018 \\
(0.026)\end{array}$ & $\begin{array}{c}0.015 \\
(0.026)\end{array}$ \\
\hline Retired & & $\begin{array}{c}0.030 \\
(0.029)\end{array}$ & $\begin{array}{l}-0.006 \\
(0.029)\end{array}$ & $\begin{array}{l}-0.008 \\
(0.029)\end{array}$ \\
\hline Inactive & & $\begin{array}{c}-0.078^{* * *} \\
(0.021)\end{array}$ & $\begin{array}{c}0.009 \\
(0.020)\end{array}$ & $\begin{array}{c}0.007 \\
(0.020)\end{array}$ \\
\hline \multicolumn{5}{|l|}{$\begin{array}{l}\text { Household composition } \\
\quad \text { (Single excl.) }\end{array}$} \\
\hline Couple & & $\begin{array}{c}0.059 * * * \\
(0.016)\end{array}$ & $\begin{array}{c}0.019 \\
(0.016)\end{array}$ & $\begin{array}{c}0.018 \\
(0.016)\end{array}$ \\
\hline Lone parent & & $\begin{array}{c}0.002 \\
(0.020)\end{array}$ & $\begin{array}{l}0.013 \\
(0.020)\end{array}$ & $\begin{array}{c}0.012 \\
(0.020)\end{array}$ \\
\hline Multi-family $\mathrm{HH}$ & & $\begin{array}{c}-0.069 * * * \\
(0.027)\end{array}$ & $\begin{array}{l}-0.018 \\
(0.027)\end{array}$ & $\begin{array}{l}-0.020 \\
(0.027)\end{array}$ \\
\hline Number of children & & $\begin{array}{c}0.048 * * * \\
(0.005)\end{array}$ & $\begin{array}{c}0.043 * * * \\
(0.005)\end{array}$ & $\begin{array}{c}0.043 * * * \\
(0.005)\end{array}$ \\
\hline Number of adults & & $\begin{array}{r}-0.015^{*} \\
(0.009)\end{array}$ & $\begin{array}{l}-0.006 \\
(0.009)\end{array}$ & $\begin{array}{l}-0.005 \\
(0.009)\end{array}$ \\
\hline \multicolumn{5}{|l|}{$\begin{array}{l}\text { Household real income } \\
\quad(£ 0-£ 9,999 \text { excl.) }\end{array}$} \\
\hline$£ 10,000-£ 19,999$ & & $\begin{array}{c}0.059 * * * \\
(0.014)\end{array}$ & $\begin{array}{l}-0.003 \\
(0.014)\end{array}$ & $\begin{array}{l}-0.002 \\
(0.014)\end{array}$ \\
\hline$£ 20,000-£ 49,999$ & & $\begin{array}{c}0.113 * * * \\
(0.015)\end{array}$ & $\begin{array}{c}0.017 \\
(0.016)\end{array}$ & $\begin{array}{c}0.019 \\
(0.016)\end{array}$ \\
\hline$£ 50,000$ or more & & $\begin{array}{c}0.126 * * * \\
(0.021)\end{array}$ & $\begin{array}{l}0.043^{*} \\
(0.022)\end{array}$ & $\begin{array}{l}0.044 * \\
(0.022)\end{array}$ \\
\hline Homeowner (Private renter excl.) & & & $\begin{array}{c}0.343 * * * \\
(0.011)\end{array}$ & $\begin{array}{c}0.328 * * * \\
(0.012)\end{array}$ \\
\hline Number of bedrooms & & & $\begin{array}{l}-0.001 \\
(0.006)\end{array}$ & $\begin{array}{l}-0.001 \\
(0.006)\end{array}$ \\
\hline
\end{tabular}


Table A4-Continued

\begin{tabular}{|c|c|c|c|c|}
\hline & $\begin{array}{c}\text { (1) } \\
\text { Distance moved } \\
\text { only }\end{array}$ & $\begin{array}{c}(2) \\
\text { Personal/HH } \\
\text { characteristics }\end{array}$ & $\begin{array}{c}\text { (3) } \\
\text { Housing } \\
\text { characteristics }\end{array}$ & $\begin{array}{c}4) \\
\text { Distance } \times \\
\text { Tenure }\end{array}$ \\
\hline \multicolumn{5}{|l|}{$\begin{array}{l}\text { Accommodation type } \\
\text { (Detached/bungalow excl.) }\end{array}$} \\
\hline Semi-detached & & & $\begin{array}{l}-0.015 \\
(0.013)\end{array}$ & $\begin{array}{l}-0.014 \\
(0.013)\end{array}$ \\
\hline Terraced & & & $\begin{array}{l}-0.023 \\
(0.015)\end{array}$ & $\begin{array}{l}-0.022 \\
(0.015)\end{array}$ \\
\hline Purpose-built flat & & & $\begin{array}{c}-0.041 * * \\
(0.020)\end{array}$ & $\begin{array}{c}-0.040 * * \\
(0.020)\end{array}$ \\
\hline Converted flat & & & $\begin{array}{c}-0.056 * * * \\
(0.021)\end{array}$ & $\begin{array}{c}-0.056^{* * * *} \\
(0.021)\end{array}$ \\
\hline \multicolumn{5}{|c|}{$\begin{array}{l}\text { House value - council tax band } \\
\text { (Up to } £ 40 \mathrm{k} \text { excl.) }\end{array}$} \\
\hline $\mathrm{Up}$ to $£ 52 \mathrm{k}$ & & & $\begin{array}{c}0.016 \\
(0.014)\end{array}$ & $\begin{array}{c}0.017 \\
(0.014)\end{array}$ \\
\hline Up to $£ 68 \mathrm{k}$ & & & $\begin{array}{c}0.000264 \\
(0.015)\end{array}$ & $\begin{array}{c}0.001 \\
(0.015)\end{array}$ \\
\hline Up to $£ 88 \mathrm{k}$ & & & $\begin{array}{c}0.016 \\
(0.017)\end{array}$ & $\begin{array}{c}0.016 \\
(0.017)\end{array}$ \\
\hline Up to $£ 120 \mathrm{k}$ & & & $\begin{array}{l}-0.016 \\
(0.020)\end{array}$ & $\begin{array}{l}-0.015 \\
(0.020)\end{array}$ \\
\hline Up to $£ 160 \mathrm{k}$ & & & $\begin{array}{c}-0.057 * * \\
(0.025)\end{array}$ & $\begin{array}{c}-0.057 * * \\
(0.025)\end{array}$ \\
\hline Up to $£ 320 \mathrm{k}$ & & & $\begin{array}{c}-0.085 * * * \\
(0.029)\end{array}$ & $\begin{array}{c}-0.085 * * * \\
(0.029)\end{array}$ \\
\hline Over $320 \mathrm{k}$ & & & $\begin{array}{c}-0.089^{*} \\
(0.051)\end{array}$ & $\begin{array}{l}-0.088^{*} \\
(0.051)\end{array}$ \\
\hline \multicolumn{5}{|c|}{$\begin{array}{l}\text { Main reasons for moving } \\
\quad \text { (Neighborhood-related excl.) }\end{array}$} \\
\hline Housing-related & & & $\begin{array}{l}-0.015 \\
(0.014)\end{array}$ & $\begin{array}{l}-0.014 \\
(0.014)\end{array}$ \\
\hline Had to leave & & & $\begin{array}{l}0.006 \\
(0.017)\end{array}$ & $\begin{array}{l}0.006 \\
(0.017)\end{array}$ \\
\hline Personal/family-related & & & $\begin{array}{c}0.012 \\
(0.014)\end{array}$ & $\begin{array}{c}0.012 \\
(0.014)\end{array}$ \\
\hline Job-related & & & $\begin{array}{c}0.054 * * * \\
(0.018)\end{array}$ & $\begin{array}{c}0.057 * * * \\
(0.018)\end{array}$ \\
\hline Government office regions & Yes & Yes & Yes & Yes \\
\hline Survey year dummies & Yes & Yes & Yes & Yes \\
\hline Constant & $\begin{array}{l}1.991 * * * \\
(0.029)\end{array}$ & $\begin{array}{c}1.093 * * * \\
(0.054)\end{array}$ & $\begin{array}{c}1.090 * * * \\
(0.060)\end{array}$ & $\begin{array}{c}1.100 * * * \\
(0.060)\end{array}$ \\
\hline $\begin{array}{l}\text { Adj. R-squared } \\
\text { No. of obs. }\end{array}$ & $\begin{array}{l}0.0041 \\
37755\end{array}$ & $\begin{array}{l}0.0383 \\
37755\end{array}$ & $\begin{array}{l}0.0675 \\
37755\end{array}$ & $\begin{array}{l}0.0677 \\
37755\end{array}$ \\
\hline
\end{tabular}

Notes: $* * *, * * *$ significance level at 1,5 , and $10 \%$ respectively. Age, sex and economic status are of household heads. 


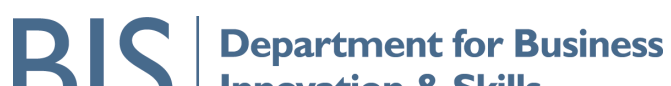 BIS}

\section{Spatial Economics Research Centre (SERC)}

London School of Economics

Houghton Street

London WC2A 2AE

Tel: 02078523565

Fax: 02079556848

Web: www.spatialeconomics.ac.uk

SERC is an independent research centre funded by the Economic and Social Research Council (ESRC), Department for Business Innovation and Skills (BIS) and the Welsh Government. 